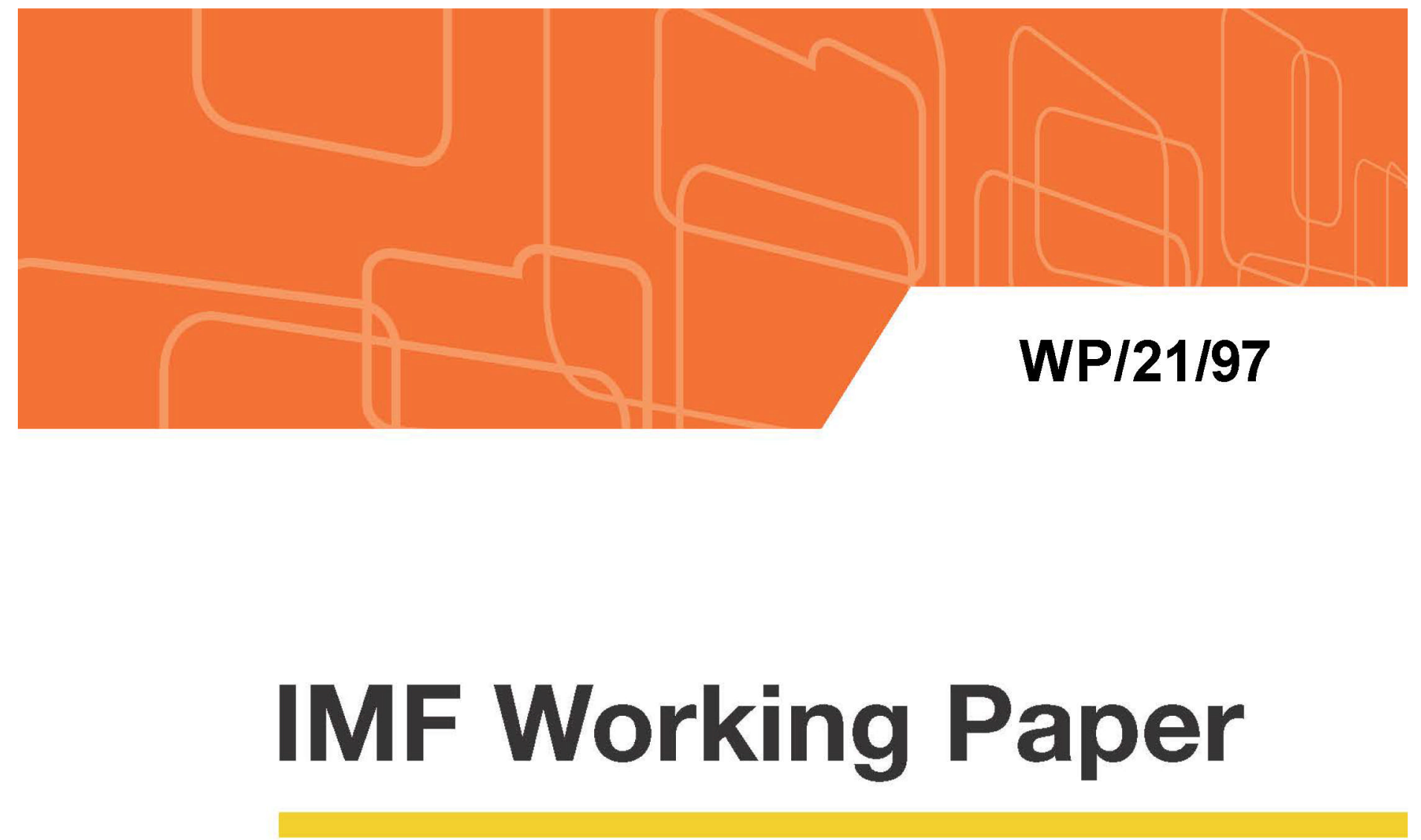

\title{
Sharing Resource Wealth Inclusively Within and Across Generations
}

by Nathalie Pouokam

IMF Working Papers describe research in progress by the author(s) and are published to elicit comments and to encourage debate. The views expressed in IMF Working Papers are those of the author(s) and do not necessarily represent the views of the IMF, its Executive Board, or IMF management.

I N T E R N A T I O N A L M O N E T A R Y F U N D 


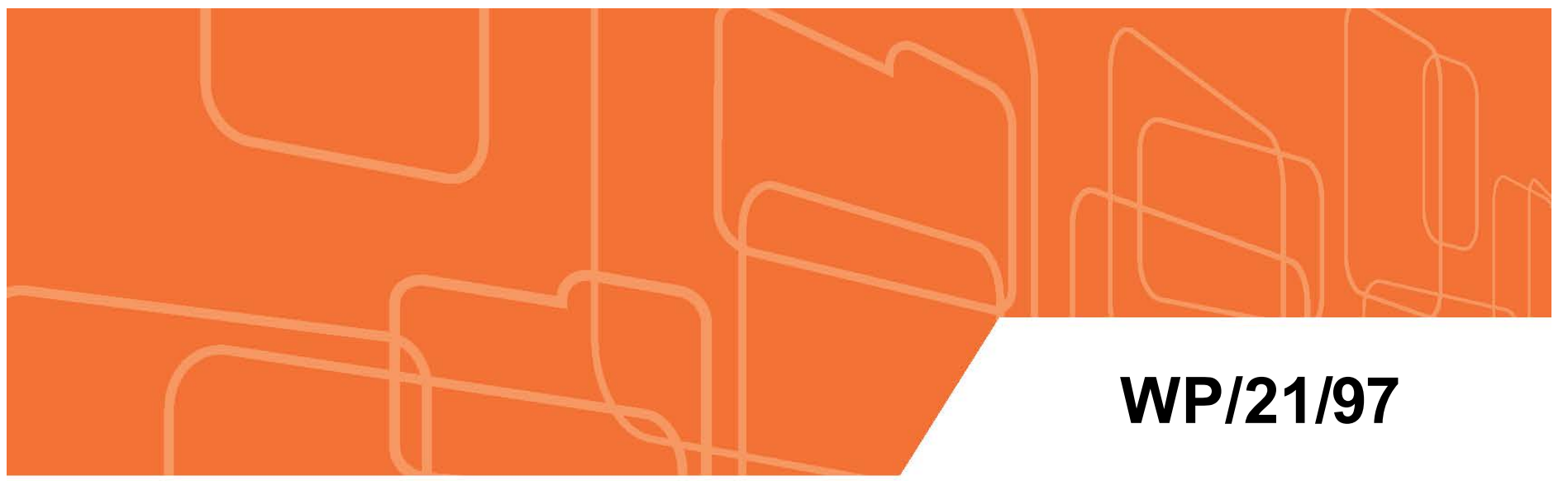

\section{IMF Working Paper}

\section{Sharing Resource Wealth Inclusively Within and Across Generations}

by Nathalie Pouokam

IMF Working Papers describe research in progress by the author(s) and are published to elicit comments and to encourage debate. The views expressed in IMF Working Papers are those of the author(s) and do not necessarily represent the views of the IMF, its Executive Board, or IMF management.

$$
\text { I N T E R N A T I O N A L M O N E T A R Y F U N D }
$$




\title{
IMF Working Paper
}

Institute for Capacity and Development

\section{Sharing Resource Wealth Inclusively Within and Across Generations \\ Prepared by Nathalie Pouokam ${ }^{1}$}

Authorized for distribution by Paul Cashin and Valerie Cerra

April 2021

\begin{abstract}
IMF Working Papers describe research in progress by the author(s) and a re published to elicit comments and to encourage debate. The views expressed in IMF Working Papers are those of the author(s) and do not necessarily represent the views of the IMF, its Executive Board, or IMF management.
\end{abstract}

\begin{abstract}
This paper discusses the main challenges faced by resource-rich nations in promoting equity; describes policy tools available for managing exhaustible natural resources; and analyzes the relationship between resource wealth and state fragility. It is argued that human capital accumulation, innovation, and technology diffusion can help escape the trap of low growth and resource dependence that plagues so many developing countries. But to make this possible, resource-rich nations must sustain strong citizen participation in the policy making to hold governments accountable and ensure the inclusive management of resource wealth.

Keywords: Natural Resources, Intergenerational Equity, Inclusive Growth, Inequality.

JEL Classification: E32, HQ32, Q34, Q38, O43.

Author's E-Mail Address: NPouokam@imf.org
\end{abstract}

${ }^{1}$ I thank Jaime Sarmiento Monroy for excellent research assistance. I am also grateful for comments received from Valerie Cerra, Barry Eichengreen, Andrew Warner, Maksym Ivanyna, Nikola Spatafora, Christian Henn, Olivier Basdevant, John Hooley, Paulo Medas, Joseph Procopio, and participants in the Inclusive Growth book seminar series organized by the IMF Institute for Capacity Development. This is a draft of a chapter that has been accepted for publication by Oxford University Press in the forthcoming book "How to Achieve Inclusive Growth", edited by V. Cerra, B. Eichengreen, A. El-Ganainy, and M. Schindler. 


\section{Contents}

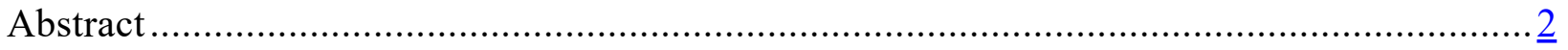

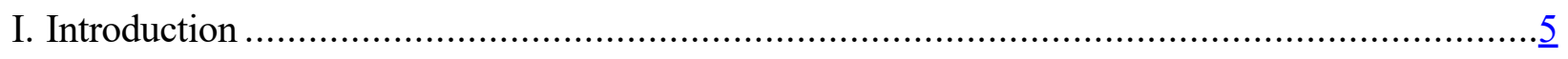

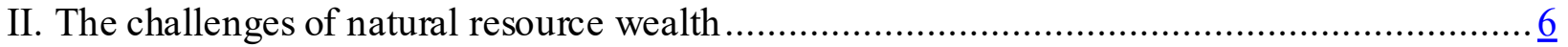

A. The challenge of measuring resource wealth ..................................................................

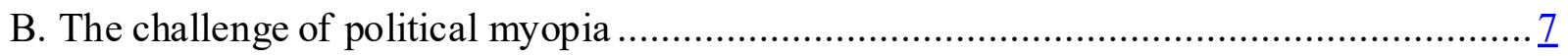

C. The challenge of falling global demand for hydrocarbon exports..................................... $\underline{9}$

III. Resource curse, Dutch disease, and exchange rate policies .......................................................

A.The resource curse and the Dutch disease......................................................................

B. Exchange rate policies for managing resource wealth ...................................................11

IV. Fiscal policy frameworks for managing resource wealth.......................................................15

A. Two frameworks for saving resource wealth: the PIH and BIH ……...........................15

B. Country examples of the PIH and BIH frameworks.....................................................16

São Tomé and Principe and the PIH framework

Timor-Leste and the Modified Permanent Income Hypothesis framework

Norway and the BIH framework

C. Fiscal rules for dealing with volatile resource revenue ……......................................19

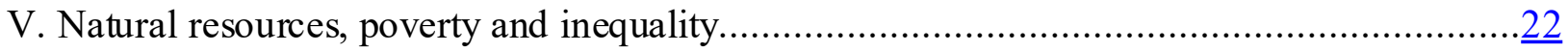

VI. Structural policy: making the case for economic diversification........................................25

A. The experience of Malaysia with economic diversification........................................26

B. The experience of Chile with economic diversification ..........................................................27

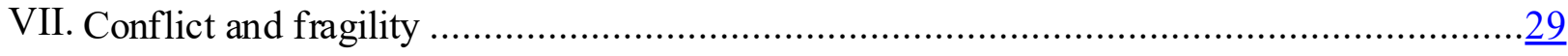

VIII. Strengthening governance in the management of resource wealth .................................31

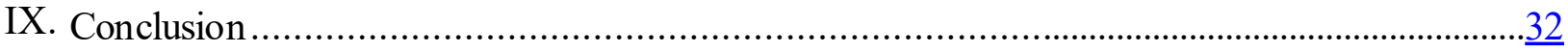

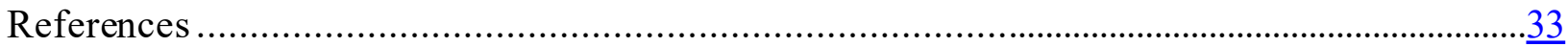




\section{Figures}

Figure 1. Exhaustibility of Natural Resources: Number of Years Left to Depletion ...................... 7

Figure 2. Resource Rents, Corruption and Competitiveness ...................................... $\underline{8}$

Figure 3. Commodity Prices and Real Effective Exchange Rates.................................. $\underline{8}$

Figure 4. Natural Resources and Govemance Indicators............................................ $\underline{9}$

Figure 5. Natural resource wealth causes volatility in government revenues....................... 19

Figure 6. Fiscal Balance and Debt in Botswana, Chile, and Norway ............................... 20

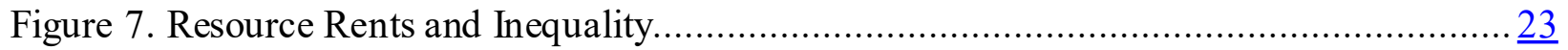

Figure 8. Poverty and Spending in Health, Education in Resource-Rich Countries................. 25

Figure 9. Military Spending and Resource Wealth in Low-Income Countries....................... $\underline{30}$ 


\section{Introduction}

The fast-paced global economy of the post-World War II era has led many countries to harness their natural capital at an unprecedented fast pace. Unfortunately, in many cases, the harnessed returns from natural resources have not been conducive to inclusive growth (Sachs and Warner, 2001) which is understood as strong and sustainable growth leading to equitably distributed socioeconomic welfare within and across generations. Rather, the depletion of many types of natural resources has often mostly benefitted a handful of people from the extracting generations. This paper discusses the main challenges faced by resource-rich nations in promoting equity, describes some of the policy tools available for managing exhaustible natural resources, and analyzes the relationship between resource wealth and state fragility.

Natural resource wealth often constitutes a large share of economic wealth, but contributes little to inclusive growth, especially in developing countries. In 2014, natural capital (including both exhaustible and non-exhaustible resources) accounted for about 50 percent of the total wealth of low-income countries. In the same year, it accounted for 3 percent of the total wealth of highincome OECD countries (The World Bank Group, 2018). Yet, over the period 1995-2014, natural capital only contributed to 10 percent of growth in low-income countries. In advanced economies, it contributed to 3 percent of growth during that period (The World Bank Group, 2018). The fact that advanced economies have been getting relatively higher returns from their resource wealth suggests that with appropriate policies, most resource-rich developing countries could grow faster than they currently do. The experience of Botswana supports this hypothesis.

Despite being plagued with persistent inequality, Botswana is one example of a developing and resource-rich country which has been successful at avoiding the vicious cycle of resource dependence and economic stagnation. ${ }^{2}$ Over the last three decades that preceded the 2008 financial crisis, Botswana remarkably grew by an average growth rate of 7.5 percent, with 40 percent of this growth being attributed to mining (Limi, 2007). According to Acemoglu and others (2002), the factors behind this outstanding performance were: efforts to improve governance, commitment to strong fiscal discipline, and strong investment in education and public infrastructure, all of which were possible thanks to Botswana's strong institutions which protect investors' property rights, provide political stability, and ensure broad citizens' participation in the policy making process. ${ }^{3}$ Between 1998 and 2007, Botswana invested on average 8 percent of GDP in education, well above the average of 3 percent seen in resource-rich countries over the same period. This paper posits that if resource-rich societies manage to strengthen their institutions and

2 According to Hillbom and Bolt (2015), income inequality in Botswana peaked in the 1970s, at the time of the shift between the cattle economy established during the colonial era, and the diamond economy. Since then, inequality has been declining in Botswa na, driven by targeted government transfers and growing incomes generated by fast and susta ined growth. Albeit still very high, Botswana's income Gini index fell from 0.61 to 0.53 between 2010 and 2015 .

${ }^{3}$ Acemoglu and others (2002) a rgues that Botswana owes its strong in stitutions to the fact that British colonialism did not destroy its pre-colonial in stitutions which were rela tively inclu sive institutions, to strong political lea dership since independence, and to the elite's interests in reinforcing institutions. 
implement sound policies, they could achieve the successful performance of Botswana, and with less inequality.

Harnessing natural resources comes with several challenges. These challenges include: the eminent exhaustibility of key natural resources; the risk that myopic governments favor the fast depletion of natural resources over a longer-term development strategy that would be conducive to a productive business climate; the risk that resource wealth fuels corruption and leaves the country trapped in a vicious cycle of poor governance and low growth; the risk of a decline in the competitiveness of non-resource based exports; and for hydrocarbon producers, the new constraints imposed by a carbon-conscious global economy. Overcoming the challenges imposed by natural resources comes with sizeable opportunities for developing countries, which in many cases are plagued with widespread poverty despite holding significant resource wealth.

In the case of fragile countries, resource wealth poses an additional challenge. Often, it serves to fuel conflict by providing a funding base for military spending that is given priority over basic social and physical infrastructure needs. For this reason, resource wealth often undermines the ability of countries to exit fragility. But fortunately, this paradoxical role of resource wealth can be avoided by committing to a transparent and sound management of the resource wealth.

Most of the challenges associated with harnessing resource wealth can indeed be overcome with an adequate policy framework. This requires: (1) adopting a resource wealth management framework that serves the joint interests of both current and future generations; (2) sustaining investment in human capital with earnest commitment to using resource wealth for educating masses; and (3) diversifying away from natural resources to curb resource dependence. As the experiences of Botswana and Norway discussed in this paper suggest, strong institutions and sustained citizen participation in the policy making process are of paramount importance in making governments accountable and ensuring the inclusive management of resource wealth. To understand how economic diversification could be achieved in resource-rich countries, this paper further proposes lessons learned from the economic diversification experiences of Malaysia and Chile. For what follows, discussions are focused on exhaustible (non-renewable) natural resources.

\section{The challenges of natural resource wealth}

\section{A. The challenge of measuring resource wealth}

Quantifying natural resource wealth is a daunting task for two reasons: (1) an accurate estimation of the quantities of commodities in the ground not only often necessitates the use of cost-prohibitive technologies, but it also requires regularly tracking the rate of extraction; and (2) forecasting commodity prices has proved to be bound to large errors caused by the highly volatile nature of shocks to commodity prices (International Monetary Fund, 2015). Accounting for this uncertainty requires a resource wealth management framework which provides regular estimates of the value of the country's resource reserves under different price scenarios (International Monetary Fund, 2015). 
In practice, economists usually keep track of two measures when estimating resource wealth. These measures are the annual resource rents-to-GDP and the time left to depletion. Resource wealth is then estimated as the net present value of current and future natural resource rents over the time left to depletion, also known as exhaustion time-(World Bank, 2011). Following a methodology used by the World Bank, the exhaustion time is typically calculated as the ratio of reserves remaining at the end of a given year, to the production level recorded in that particular year. Because this approximation of the time to depletion does not account for the possibility of future discoveries, it provides only a basic and crude estimate for the exhaustibility of key natural resources. This is an imperfect, yet useful, starting point in assessing the urgency to transform from a resource-based economy to a more diversified economic structure.

The exhaustibility of major types of natural resources is a binding constraint. For many resource-rich countries, the exhaustion of proven reserves of key natural resources is in fact expected to happen in the foreseeable future, given current production rates (Figure 1). For instance, in 2019, the world median expected number of years to depletion was 29 years for oil reserves, and 49 years for cobalt reserves. In other words, many countries dependent on either oil or cobalt could take less than one generation to become resource-poor.

Figure 1. Exhaustibility of Natural Resources: Number of Years Left to Depletion

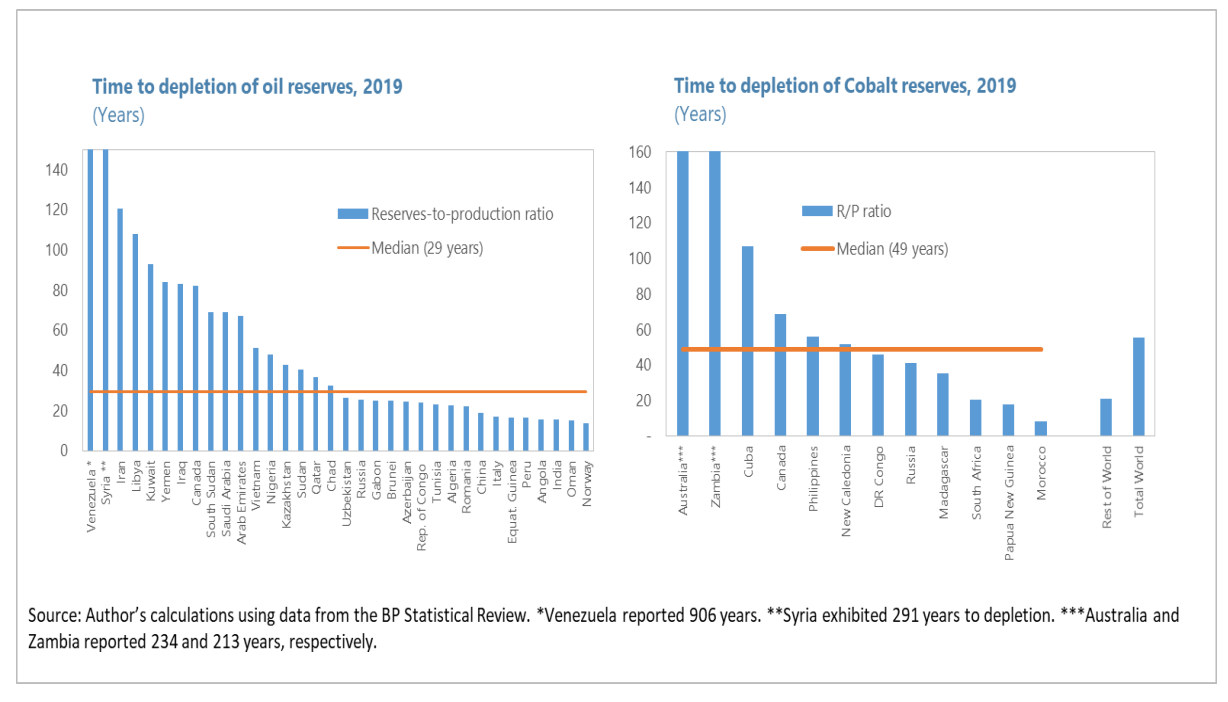

\section{B. The challenge of political myopia}

The abundance of natural resources has lured many countries into delaying efforts to promote a business climate favorable to growth in the non-resource sector. When governments are short-sighted because of political instability or a lack of government accountability, they are often unwilling to champion reforms to improve the business climate and support an expansion of non-resource-based sectors. This could explain in part why so many resource-rich developing countries continue to lag behind their resource-poor peers, both in terms of export diversification and export quality (Figure 2). Unfortunately, specialization in natural resources has also usually hindered macroeconomic stability in these countries. 
Figure 2. Resource Rents, Corruption and Competitiveness

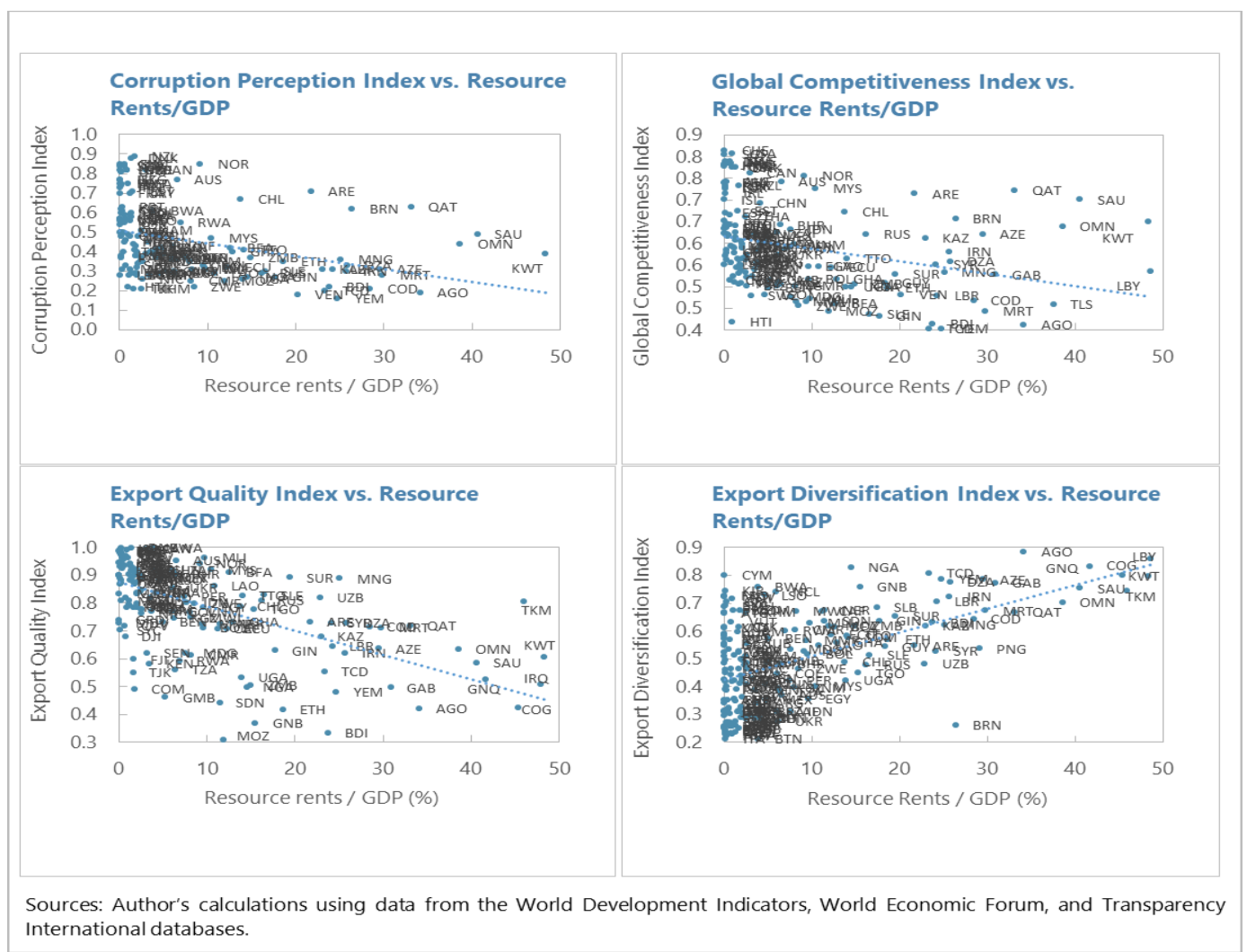

Indeed, most commodity exporters have been at the mercy of fluctuations in global commodity prices. For instance, in resource-rich countries, government revenues over the last two decades have almost perfectly mirrored fluctuations in global commodity prices (Figure 5), reflecting heavy dependence on resource windfalls. Likewise, real exchange rates have also been driven by commodity price swings (Figure 3), often to the detriment of competitiveness and the ability to develop export capacity in non-commodity traded goods. Such economic volatility has contributed to further weakening growth and exacerbating inequality (Goderis and Malone, 2011).

\section{Figure 3. Commodity Prices and Real Effective Exchange Rates}

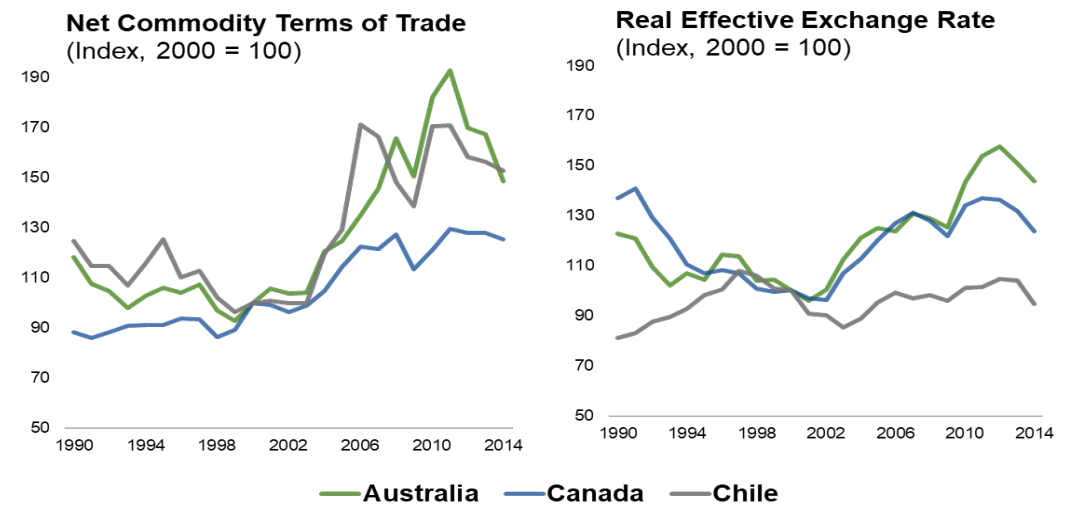


If not properly managed, natural resource wealth could fuel corruption and leave the country trapped in a quagmire of poor governance, resource dependence, and slow growth. The data indeed suggests a negative association between governance quality and resource abundance (Figure 4). ${ }^{4}$ Two mechanisms may explain this negative correlation. First, weak institutions and poor governance create opacity in public financial management and support corruption which polarizes the ownership of the resource capital, ultimately creating long-lasting vested interests for resource dependence. Second, natural resource rents fuel corruption and slow down institutional reforms, undermining the long-term growth potential. The abundance of natural resources therefore creates even higher stakes for reinforcing political accountability and committing to policy frameworks that would help ensure that corruption does not stand in the way of institutional reforms and long-term growth.

\section{Figure 4. Natural Resources and Governance Indicators}

(Estimate value, 2019)

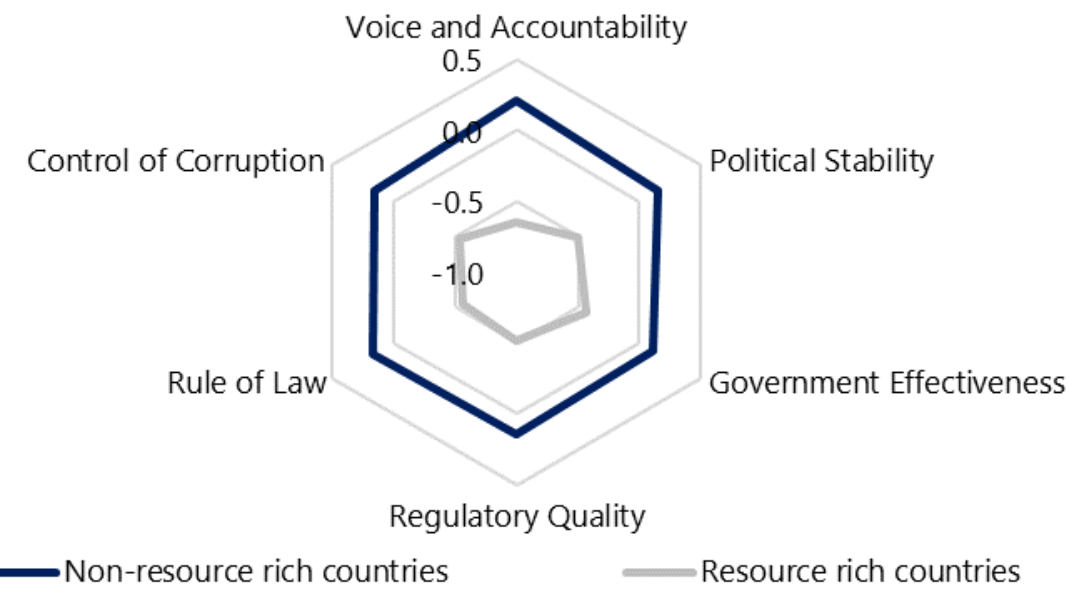

Source: Author's calculations using data from the Worldwide Governance Indicators database. Note: values between -2.5 to 2.5 (best).

\section{The challenge of falling global demand for hydrocarbon exports}

Greater global awareness of the negative impact of fossil fuel energy consumption on the environment has created new challenges for carbon-rich countries. These challenges include the risk of a permanent fall in global carbon prices if global demand for these resources (essentially oil, gas and coal) were to plummet in response to increased carbon taxes (International Monetary Fund, 2019) while global supply were to surge, caused by hydrocarbon companies extracting faster in anticipation for higher future carbon taxes - the green paradox - (World Bank, 2018); and Sinn, 2008). In the process, speedy efforts to increase carbon production would also imply a

\footnotetext{
${ }^{4}$ The positive a ssociation between corruption and resource wealth is discussed in (Veisi, 2017).
} 
misallocation of resources away from promising sectors for which returns on investment would be perceived as less immediate.

\section{Resource curse, Dutch disease and exchange rate policies}

\section{A. The Resource curse and the Dutch disease}

Resource wealth tends to be associated with slower economic growth. A large body of the economic literature has documented the negative association between resource dependence and per capita GDP growth, a phenomenon known as the "resource curse". The term "resource curse" was initially used in the case studies of Gelb (1989) and Auty and Warhurst (1993) to describe the poor growth performances of mineral-rich developing countries, namely Zambia, Zaire (current Democratic Republic of Congo), Bolivia, and Peru (Auty and Warhurst, 1993); and oil-rich developing countries, namely Nigeria, Ecuador, Indonesia, Trinidad and Tobago, and Venezuela (Gelb, 1989). The seminal empirical study of Sachs and Warner (1991) establishes that countries starting with relatively higher ratios of natural resource-based exports to GDP in 1971 had relatively lower average growth rates over the subsequent period 1971-1989, including after controlling for initial percapita income, trade policy, government efficiency, investment rates, and other variables relevant for economic growth. Papyrakis and Gerlagh (2007) confirms this empirical finding for the United States, suggesting that US states with relatively large natural resource wealth endowments grew less over the period 1986-2000 than the rest of the country, because they not only had poorer growth promoting outcomes in terms of investment, schooling, openness, and R\&D expenditure, but also had more corruption. James and Aadland (2011) similarly finds a negative correlation between resource wealth and economic growth at the more disaggregated US county level, including for more recent periods.

If the existence of a negative relationship between resource wealth and growth is usually accepted as a given, there is much less consensus about the underlying reasons explaining such relationship -see James (2015) for a detailed review. The mechanisms highlighted in the economic literature to explain the resource curse to a large extent echo the previous discussion of challenges associated with resource wealth. Explanations for the resource curse include that: (1) resource wealth tends to prolong anti-growth policies such as autarkic trade policies (Auty, 1994); (2) resource wealth creates opportunities for rent seeking behaviors which diverts entrepreneurial talent away from productive business enterprise (Torvik, 2002); (3) resource wealth raises the stake for social conflict as factions of society compete to take control of the natural resource (Collier and Hoeffler, 1998); (4) resourcewealth creates a false sense of economic security, leading to underinvestment in human capital (Gylfason, 2001); and (5) resource wealth crowds out other growth-promoting industries such as manufacturing, a phenomenon known as the Dutch disease (Matsuyama, 1992; Sachs and Warner, 1999).

The term "Dutch disease" was initially used to describe the decline in traditional industries in the Netherlands after the discovery and development of natural gas industries in the 1960s. In the Netherlands, it started with the discovery of the vast Slochteren natural gas field in the Groningen province in 1959 (Hutchison, 1994), followed with a period of higher real wage growth 
and real exchange rate appreciation which made non-hydrocarbon exports more expensive and therefore less competitive (Hutchison, 1994; Bjørnland and Thorsrud, 2016). The common explanation for the Dutch disease phenomenon is that commodity booms create a reallocation of resources toward the commodity sector which bids up wages, causing the non-resource tradable sector (typically manufacturing and agriculture) to become less competitive (Corden and Neary, 1982). Usually, the real exchange rate appreciates as domestic demand for both tradable and nontradable goods (typically services) increases, pushing non-tradable goods prices up while tradable goods prices remain fixed at international levels. The increase in the relative price of non-tradableto-tradable goods in a context of booming commodity prices causes factors of production to move from the non-resource tradable sector to the non-tradable sector, which leads to an expansion in non-tradable services and a decline in tradable manufacturing and agriculture sectors (Ismail, 2010).

Like the Netherlands, many other resource-rich countries have witnessed a decline in traditional sectors after periods of commodity booms, often following a natural resource discovery or a surge in natural resource commodity prices. Evidence for the manifestation of the Dutch disease in the manufacturing sector in response to unanticipated changes in real commodity prices has been established at quarterly frequency for Canada (Charnavoki and Dolado, 2014) and Australia (Dungey et al., 2014). Using annual-frequency panel data including oil-exporting developing countries and advanced economies, Ismail (2010) finds that permanent increases in oil prices over time negatively impact output in manufacturing, and also lead to an increase in the relative price of labor to capital, as consistent with the Dutch disease. The cumulative impact of permanent oil windfall shocks reported by Ismail (2010) is large: a 3.4 percent reduction in value added across industries for a 10 percent increase in oil windfall, over a four-year period. While these conclusions contrast sharply with the study of Spatafora and Warner (1995) who did not find such cross-country evidence of Dutch disease in the manufacturing sector following oil booms, they nevertheless point to an important vulnerability caused by resource wealth: the risk of a decline in the non-resource economy if commodity booms are not accompanied with appropriate policies to support traditional sectors.

\section{B. Exchange rate policies for managing resource wealth}

A one-size-fits-all approach should not be used to determine which exchange rate regime would be most appropriate to manage resource wealth. Generally speaking, an appropriate exchange rate policy is one that in coordination with other macroeconomic policies, prevents internal and external imbalances in the economy by helping achieve full employment, price stability, and current account levels that are consistent with economic fundamentals. For a resource-rich country, the Dutch disease provides an additional channel through which imbalances may build up in the form of an overvaluation of the real exchange rate. This further complicates the choice of an exchange rate regime.

There seems to be no universal solution. Resource-rich countries have experimented all types of exchange rate regimes, ranging anywhere between free-floating regimes and fixed exchange rate 
regimes (including intermediate regimes such as managed floating and adjustable peg regimes); albeit with some degree of predominance of fixed-exchange rate regimes. ${ }^{5}$ Wills and van der Ploeg (2014) report that about seventy-five percent of resource-dependent countries choose to peg their currency, compared to 65 percent among non-resource-dependent countries.

Frankel (2003) argues that country characteristics, especially the nature of the most prevalent disturbances (whether internal or external), should govern the choice of the exchange rate regime. Frankel (2003) suggests for instance that in the absence of major internal disturbances, a commodity exporter would gain most from floating rather than pegging its currency, as a floating currency would provide some degree of insulation against the impact of fluctuations in commodity prices, while still allowing to effectively use monetary policy to correct for internal imbalances (internal balance is achieved when output is at its full potential and there is price stability). ${ }^{6}$ In the case of a commodity boom for example, a floating exchange rate regime would allow for some nominal exchange rate appreciation which could prevent the economy from overheating if the commodity boom is also causing large and positive spillovers to the rest of the economy. On the other hand, if internal shocks are the most predominant source of concern, Frankel's argument would call for pegging the currency to curb uncertainty coming from exchange rate volatility, while using fiscal policy to address internal imbalances. This argument unfortunately provides a useful but too simplistic view of thinking about the choice of an exchange rate regime for a resource-rich economy. Such decision should carefully weigh the benefits and costs associated with fixed and floating exchange rate regimes.

The choice of an exchange rate regime for a resource-rich country should take into consideration how different rate regimes would affect the country's ability to deal with the challenges associated with resource wealth. Some key advantages of a fixed exchange rate regime are that: (1) it eliminates the uncertainty created by exchange rate volatility; (2) it reduces international transaction costs; and (3) it can help anchor inflation expectations to desirably low levels when the country's currency is pegged to a currency managed with strong monetary discipline (Frankel, 2000). These advantages come at the cost of having to relinquish the use of monetary policy to achieve macroeconomic stability. More so, with a fixed exchange rate regime, fluctuations in commodity prices translate one-for-one into fluctuations in nominal receipts, as the exchange rate does not play the role of shock absorber. A floating exchange rate regime on the other hand allows the coordinated use of monetary policy and fiscal policy to achieve internal and external balance, and provides a mechanism through which fluctuations in the nominal exchange rate can help absorb external shocks. For instance, in an era of falling commodity prices, the negative shock caused to foreign exchange inflows could cause a nominal depreciation of the exchange rate for a commodity exporter, and potentially provide a much-needed boost to the economy (precisely by making exports more competitive and by amortizing the negative shock to

\footnotetext{
${ }^{5}$ See Frankel(2003a) for a detailed survey.

${ }^{6}$ In the MundellFlemming framework, monetary policy is ineffective in a fixed exchange rate regime when there is perfect capital mobility.
} 
resource revenues converted in the domestic currency). These advantages of a floating exchange rate regime unfortunately often come at the cost of poorly anchored inflation expectations if the central bank is not successful at credibly committing to strong monetary discipline, and a possible surge in external debt when the exchange rate depreciates to accommodate for falling commodity prices.

Despite the potential benefits of automatic stabilization provided by a floating exchange rate, commodity exporters have often attempted to stabilize their exchange rates in the face of negative terms-of-trade shocks. Nakatani (2018) documents the use of the policy of exchange rate stabilization by Papua New Guinea - an oil and gas exporter-which in the context of falling oil and gas prices, intervened heavily in the foreign exchange market between June 2014 and May 2016 to contain the depreciation of its currency relative to the U.S. dollar. During this period, oil and gas prices fell by about 60 percent, and the Papua New Guinea Kina depreciated relative to the U.S. dollar by roughly 24 percent, with the central bank depleting its foreign reserves to support its currency. Nakatani has described Papua New Guinea's policy decision to control the exchange rate as a de facto switch from a floating to a fixed regime motivated by concerns about the inflationary impact of currency depreciation and the limited responsiveness of net exports to the exchange rate.

Real exchange rate stabilization to address positive terms of trade shocks is possible but usually at a cost. In fact, neither a fixed or floating exchange rate regime provides complete insulation against the Dutch disease, which in the first case manifests through domestic inflation, and in the latter comes mainly through nominal exchange rate appreciation (Lama and Medina, 2012; and Frankel). However, a fixed exchange rate regime allows for some degree of real exchange stabilization, especially if inflation is relatively stable for the domestic economy and major trade partners. Stabilizing the real exchange rate in the context of booming commodity prices can provide welcome support to a dragging tradable non-resource sector (especially if there are learning by doing externalities associated with production in the manufacturing sector for instance), this often comes at the cost of higher macroeconomic volatility (Lama and Medina, 2012). This is because when policy intervention after a surge in commodity prices limits the appreciation of the real exchange rate to support the tradable non-resource sector, the role of the nominal exchange rate as a shock absorber is partially lost, and resources are inefficiently reallocated away from the booming commodity sector, despite welcome support provided to falling non-commodity exports.

Assessing the benefits of real exchange rate stabilization as a policy to address the Dutch disease therefore requires comparing the welfare gains from preventing the decline of the non-resource tradable sector with the welfare costs of potentially greater macroeconomic volatility. The study of Lama and Medina (2012) carries out this quantitative task for the Canadian economy, and finds the benefits of real exchange rate stabilization to be inferior to the cost of higher macroeconomic volatility. The authors concluded that their study provides theoretical support for the Bank of Canada's policy of not intervening in the foreign exchange market. A different conclusion may be reached for a developing economy for which there are greater reasons 
to be concerned about de-industrialization as a by-product of the Dutch disease. In such context, the question to ask is instead how effective real exchange rate stabilization is at preventing a decline of the non-resource economy when commodity prices are rising. The answer to this question depends on the responsiveness of non-resource exports to changes in the real exchange rate, which in turn hinges on several factors, including the adequacy of the supply of skills needed to produce non-resource export goods, and the quality of the business climate.

Wills and van der Ploeg (2014) pushes the argument one step further in favor of real exchange rate stabilization, suggesting that in developing countries, a peg could serve as an insurance policy against the failure of the sovereign wealth fund. This study argues that committing to a stable real exchange rate during a resource boom by accumulating reserves allows the central bank to build a de-facto sovereign wealth fund in the long run if the government has failed to create one, for instance because of corruption or fear of raiding. Pegging in this sense provides a commitment device for ensuring that over time, windfall from commodity booms are saved and spread across generations. However, for reserves to effectively serve this goal, a credible mechanism should be in place to ensure that the government does not use the accumulated reserves to finance budget needs. Such mechanism should be based on a transparent institutional framework which explicitly aims to spread the resource wealth equitably across generations. The case of the Norwegian sovereign wealth fund discussed in the next section provides a good example of how a transparent management of resource wealth can be achieved with a proper fiscal framework.

Could pegging the export price be the ideal exchange rate policy for a commodity exporter specialized in the production of one major commodity? This is the proposition put forth by Frankel (2003b) who argues that pegging the export price could provide the best of all worlds. It would deliver automatic accommodation to terms of trade shocks, similar to floating exchange rates, while retaining the credibility-enhancing advantages of a nominal anchor, similar to pegs to currencies with strong monetary discipline. Practically, pegging the export price of a specific commodity would amount to committing to fixing the price of that commodity in terms of the domestic currency. This would imply for instance that the domestic currency would depreciate to accommodate a fall in the commodity chosen as a peg, hence providing a needed boost to the economy.

Pegging the export price also has the merit that it does not leave the economy subject to fluctuations in the exchange rate of another currency, like it would be the case with a hard peg to a major currency. In fact, a currency pegged to the dollar or the euro could bring the economy into a recession if the peg appreciates to help stabilize an overheating American or Euro-zone economy. With a peg to the export price, this problem disappears but a new problem emerges: that of the choice of the commodity to use as peg, especially when the country exports several commodities that have varying degrees of volatility and do not always comove. Also, with a peg to the export price, the Dutch disease remains a threat. Clearly, if the nominal exchange rate appreciates in response to a surge in the price of the commodity that the country specializes in, non-resource-based exports could become less competitive, and the standard Dutch disease symptoms could ensue.

(C)International Monetary Fund. Not for Redistribution 
In sum, there is no definite solution for the choice of the appropriate exchange rate policy for a resource-rich country. This decision has to be made based on every country's special circumstances, taking into consideration the advantages and disadvantages of different exchange rate regimes. Nevertheless, theory and evidence suggest that exchange rate policies are not the most effective way to address the Dutch disease, for which there seems to be no short-term cure. The key strategy is to diversify the economy over time, so that Dutch disease symptoms could be reduced as the economy becomes less dependent on natural resources. This is discussed later.

\section{Fiscal policy frameworks for managing resource wealth}

The fiscal policy framework should be tuned to ensure that the management of the resource wealth promotes an equitable sharing of the resource dividend across and within generations, limits the impact of fluctuations in commodity prices on the rest of the economy, and fully supports human capital accumulation and social cohesion. As examples, the Permanent Income Hypothesis (PIH) and the Bird-in-Hand (BIH) frameworks have often been used to institutionalize savings for future generations. This has usually been done in combination with fiscal rules that help to shelter the economy from the deleterious impact of large fluctuations in commodity prices.

\section{A. Two frameworks for saving resource wealth: the PIH and BIH}

The management of natural resource wealth to promote intergenerational equity can be achieved with fiscal frameworks designed to smooth the spending of natural resource windfalls over time. Two examples of such frameworks are the Permanent-Income Hypothesis $(\mathrm{PIH})$ and the Bird-in-Hand (BIH) which specify how much of the resource rents should be spent (as measured by the non-resource primary deficit) and how much should be saved for future generations. The PIH framework restricts spending to the interest income generated by the net present value of current and future resource windfalls - the permanent income, while the BIH framework restricts spending to the interest gains on the natural resource investment fund itself. These frameworks are useful commitment devices to ensure that the benefits of natural resource windfalls get spread out across generations. Both frameworks offer predictability and a clear understanding of the weight given to future generations in the allocation of resource wealth. However, to serve their purposes, they require unequivocal transparency. Full disclosure of all operations related to the management of savings funds for future generations is needed to help create the foundation for a check and balance system capable of bringing strong discipline to the management of natural resource wealth.

The PIH and BIH frameworks could be modified to accommodate developing countries' needs for investment in human capital and public infrastructure. In fact, the $\mathrm{PIH}$ and $\mathrm{BIH}$ frameworks assume that the long-term rate of return on the savings fund intended for future generations exceeds the marginal social return on other assets. But in most developing countries the marginal returns to investments in human capital and public infrastructure are still very high (Humphrey et al., 2007). The successful experiences of Botswana suggest a practical approach to accounting for these investment needs: institutionalizing a savings fund for future generations (the 
Pula Fund) to enforce the proper use of natural resource windfalls, while also prioritizing spending to favor human capital and public infrastructure investments.

In Botswana, the prioritization of development-promoting spending is institutionalized in the Sustainable Budget Index (SBI) rule which requires that mineral revenues finance “investment expenditure", exclusively (Iimi, 2007). This rule defines investment expenditure as development expenditure and recurrent spending on education and health. The SBI rule works in tandem with the Pula Fund in which financial assets are invested in a long-term basis.

Iimi (2007) recognizes three institutional pillars supporting Botswana's sound management of resource wealth: (1) in recognition of the need for government accountability, Botswana's Ministry of Minerals, Energy and Water Resources is charged with responsibility for natural resource regulation and management; the Directorate of Corruption and Economic Crime established in 1994 serves as an independent anticorruption authority, reporting corruption cases directly to the president; and (3) there is independence between the attorney general and the government, as established by the constitution.

\section{B. Country examples of PIH and BIH frameworks}

\section{São Tomé and Príncipe and the PIH framework}

São Tomé and Príncipe was the first country in Africa to formally adopt the Permanent Income Hypothesis (PIH) framework. In December 2004, São Tomé and Príncipe promulgated the Oil Revenue Management Law for the management of oil revenues (Segura, 2006). The law required the central bank to open the National Oil Account (NOA) with a custodian foreign bank, on behalf of the government, for the purpose of managing resource wealth. The NOA was to be divided into two subaccounts: the "Unrestricted Part of the National Oil Account" in which all oil revenues would be deposited, and a "Permanent Fund" for future generations, into which the remaining balance of the Unrestricted subaccount would be transferred once a year, after the annual single transfer to the budget. It was established that the resources deposited in the NOA would be managed by the Management and Investment Committee composed of five members, among them the Minister of Finance and the President of the central bank. The Petroleum Oversight Commission including representatives of the civil society was created to ensure permanent monitoring and auditing of all transactions related to oil revenues and resources. To protect the fund from political pressures that can lead to its depletion, a rule was established to limit withdrawals from the Permanent Fund in any single year to a maximum of 20 percent of the accumulated assets (International Monetary Fund, 2012).

São Tomé and Príncipe's Oil Revenue Management Law stipulates that the amount of oil revenues to be saved in the Permanent Fund would be decided annually, based on a PIH framework aiming to support government spending, including after the exhaustion of oil resources. Namely, the law requires that every year, the amount of oil revenues transferred to fund the national budget does not exceed the lesser of: 
(1) the sum of (A) the long-term real rate of return multiplied by the balance of the Permanent Fund on June 30 of the previous year, and (B) the long-term real rate of return multiplied by the expected present value of future oil revenues on June 30 of the previous year; and

(2) the sum of: (A) the long-term real rate of return multiplied by the balance of the Permanent Fund on June 30 of the previous year, and (B) the balance of the "Unrestricted" subaccount of the NOA — in which current oil revenues are deposited — on June 30 of the previous year (Sao Tome and Principe, 2004). This second term reflects a conservative approach which helps limits the downside risks from overly optimistic forecasts of future revenues in the calculation of the net present value.

For the purpose of oil revenue management, the long-term real rate of return used is the real rate of return expected on a portfolio composed of assets proportionate to the assets held in the Permanent Fund during the same period, and is capped at 5 percent.

Timor-Leste and the Modified Permanent Income Hypothesis framework

Timor-Leste's approach to oil wealth management under the Petroleum Fund law follows the PIH but with some flexibility. Specifically, the saving policy adopted makes it possible to spend more than the level of sustainable spending, but with authorization from Parliament (Kim et al., 2005). The level of sustainable spending is calculated every fiscal year, as the product of a long-term real rate of return of 3 percent on the one hand, and the sum of the current balance of the Petroleum Fund and the net present value of all current and expected future income flows from oil reserves on the other hand. Parliament could for instance authorize an increase in spending above the sustainable level to meet urgent needs for public infrastructure. Parliament could also require a level of spending below the sustainable level if warranted by limited absorption capacities.

The Modified Permanent Income Hypothesis (MPIH) Framework adopted by Timor-Leste can help accommodate a more front-loaded spending path than a traditional PIH framework. In principle, the flexibility of the spending rule allows financial assets to be drawn down for a few years during the scaling up of public investment projects, the goal being to later offset the impact on the oil savings fund with fiscal adjustment (International Monetary Fund, 2012). If the scaling up of investment later leads to increasing non-resource revenues, the need for fiscal adjustment to compensate for the initial draw down could be eliminated. The requirement to provide justification to parliament when the amount of spending planned is higher than the level indicated by a PIH helps to discipline the choice of investment projects that are undertaken as part of the national development strategy. For instance, to ensure that the public investment scaling up program produces the benefits expected under the MPIH, the government of Timor-Leste has created institutions that are responsible for project appraisal, procurement, and monitoring within the budget process (International Monetary Fund, 2012). 
Timor-Leste's flexible approach shows how the PIH could be modified to address development needs in a manner that is consistent with the well-being of both current and future generations. However, the approach used by Timor-Leste to modify the PIH framework does not fully offset the risk that the expected returns to the investment projects undertaken could fail to materialize. If the level of fiscal adjustment later needed to compensate future generations is gauged unsustainable by future governments due to a poor economic outlook, future generations could be permanently made worse off.

Norway and the BIH framework

Norway is one of the largest oil and gas producer in the world, and a pioneer of the Bird-inHand approach with its sovereign wealth fund, the Government Pension Fund Global (GPFG). The GPFG was originally named the Government Petroleum Fund. It was established by the Government Petroleum Fund Act of 1990 which stipulated that its operational management was to be carried out by Norges Bank, under a management agreement with Norway's Ministry of Finance which would exercise oversight, including setting guidelines for benchmark and risk limits (Backer, 2009).

Since receiving its first transfer in 1996 (Government of Norway, 2015), the GPFG has been one of the fastest-growing Sovereign Wealth Fund in the world. In October 2019, its value reached 10 trillion Kroner (1.15 trillion US dollars) — (Norges Bank Investment Management, 2020). This success has been attributed to a governance framework featuring a high degree of transparency in the management of the GPFG, to Norway's commitment to its fiscal rule, and to a carefully chosen investment strategy (International Monetary Fund, 2008).

The Norwegian model of sovereign wealth fund management has been applauded as an exemplary model of transparent governance (International Monetary Fund, 2008). The GPFG's institutional framework sets clear guidelines and expectations for the roles of the Ministry of Finance and Norges Bank. The Ministry of Finance reports regularly on the GPFG's governance framework, its goals, its investment strategy and results, and its ethical guidelines. As the Fund's operational manager, Norges Banks publishes quarterly and annual reports on the fund's management. These reports include information on the fund's performance and an annual listing of all investments. Regularly, information is also made available on the fund's voting at shareholders' meeting decisions.

Norway's fiscal rule has facilitated the integration of the Fund's net allocation decision with fiscal policy (International Monetary Fund, 2008). The fiscal rule sets the limit on the central government's non-oil structural deficit at around 4 percent of the assets of the GPFG. Because 4 percent is the estimated long-run real rate of return (Government of Norway, 2015), the rule therefore amounts to saving the fund's capital and spending only its return, as typical in a BIH approach. The integration of the GPFG's saving and spending rule with the fiscal rule is one of the praised features of Norway's approach to sovereign wealth fund management (International Monetary Fund, 2008). It provides a unified accountability framework for the government to the people of Norway regarding the use of petroleum revenues and the rentability of the GPFG. 
The GPFG's successful investment strategy builds on four pillars. First, the fund has a stake in sustainable global development because it targets long-term returns that are environmentally and socially responsible (Government of Norway, 2020b). Second, the fund follows clear guidelines for risk limits (for instance, a minimum of 7.5 per cent of the net asset value of the fund is to be held in treasury bonds issued by the governments of France, Germany, Japan, the United Kingdom and the United States of America - Government of Norway, 2020b). Third, the fund diversifies its investment portfolio by setting a limit to how much may be invested in a single company's equity (Government of Norway, 2020b). As of 2020, the GFPG holds equity in about 9,000 companies with headquarters in 74 countries (Government of Norway, 2020a). Finally, to help protect the krone against large foreign exchange fluctuations generated by the petroleum industry, the fund invests exclusively abroad (Government of Norway, 2020a).

\section{Fiscal rules for dealing with volatile resource revenue}

Large fluctuations in commodity prices undermine the ability of resource-rich countries to leverage their resource-wealth to sustain long periods of stability and prosperity. In the absence of countercyclical fiscal policy which builds buffers during commodity booms, fluctuations in commodity prices directly translate into fluctuations in natural resource revenues and spending. Studies have shown that government revenues are particularly vulnerable to termsof-trade shocks in resource-rich countries (Figure 5), due to the significant dependence on the resource sector and also to the high elasticity of non-resource revenues with respect to GDP (von Haldenwang \& Ivanyna, 2018). Countercyclical fiscal policy is therefore particularly useful in resource-dependent countries as it helps provide a stable base for spending, therefore helping to avoid the temptation of increasing distortionary taxes in the face of negative shocks to commodity prices. Unfortunately, experience shows that fiscal policy in most resource-rich countries has been mainly procyclical, due to overoptimism in good times, but also to rent-seeking behaviors (International Monetary Fund, 2015).

Figure 5. Natural resource wealth causes volatility in government revenues

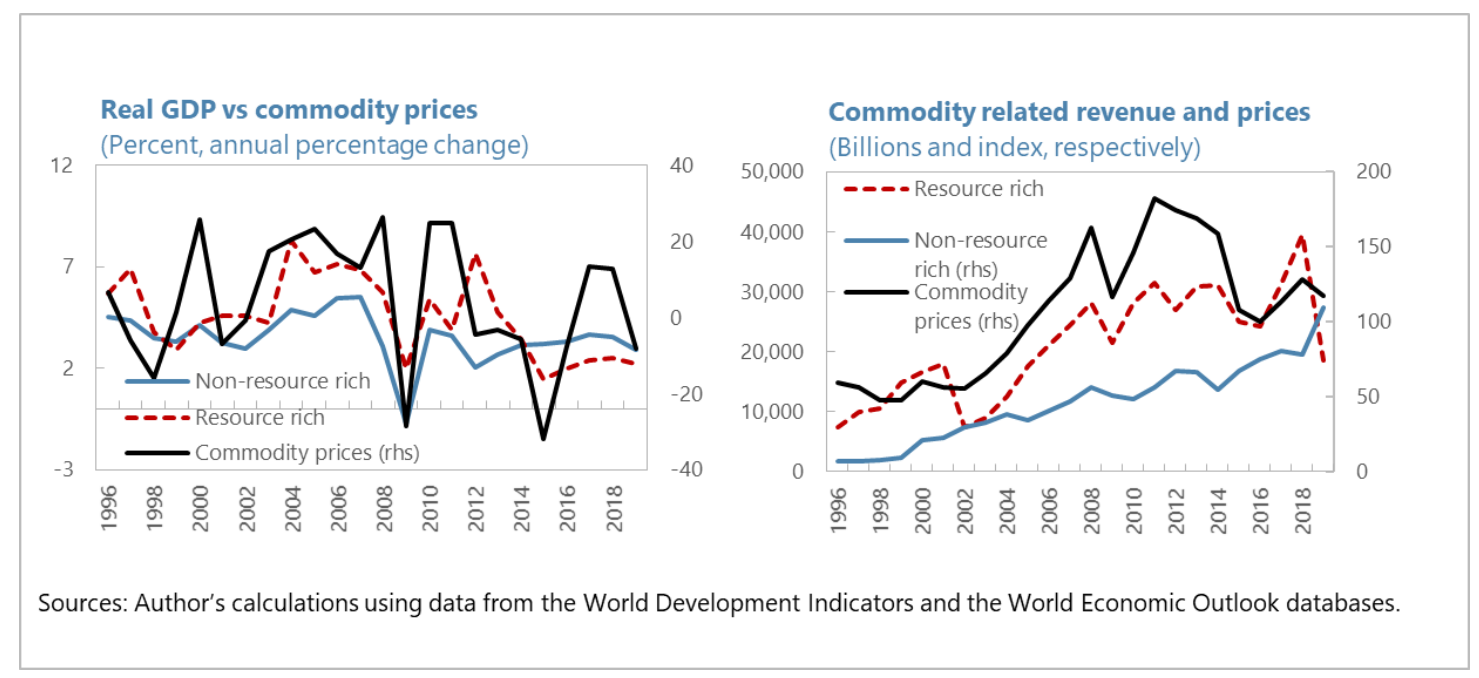

CInternational Monetary Fund. Not for Redistribution 
Fiscal rules could be a powerful commitment device for the countercyclical management of natural resource wealth. Fiscal rules in resource-rich countries have typically been formulated either as a floor on the fiscal balance -as in Chile and in the Central African Economic and Monetary Community (CEMAC) - or as a constraint on the flows of revenues to and from natural resource funds as in Norway (International Monetary Fund, 2015). Empirically, countries that have been successful at effectively using fiscal rules to promote countercyclical fiscal policy typically have strong institutions (International Monetary Fund, 2015).

A weak institutional framework challenges the enforcement of fiscal rules and leaves fiscal policy decisions at the mercy of political pressure and off-budget spending. For instance, Chad, Ecuador, Papua New Guinea all had unsuccessful experiences with fiscal rules. In these countries, weak enforcement and increased spending pressures ultimately led to the abandon of the sovereign funds which were judged incompatible with the budget needs (Keiko Takahashi, 2010; and International Monetary Fund, 2015).

\section{Country examples of fiscal rules for managing natural resource revenue volatility}

Botswana, Norway, and Chile are examples of countries that have used fiscal rules to promote countercyclical fiscal policy. The experiences of Botswana and Norway were met with success because: (1) they were both successful at striking the right balance between flexibility and credibility in the design of their fiscal rules ; and (2) they have achieved credibility in the implementation of their fiscal rules by limiting the number of deviations from the rules. Consequently, both countries have not only enjoyed solid growth over extended periods, but they have also managed to keep public debt at relatively low levels (Figure 6). In the case of Chile, success has been to some extent mixed, as the global financial crisis has complicated the ability of the country to commit credibly to its fiscal rule.

Figure 6. Fiscal Balance and Debt in Botswana, Chile, and Norway

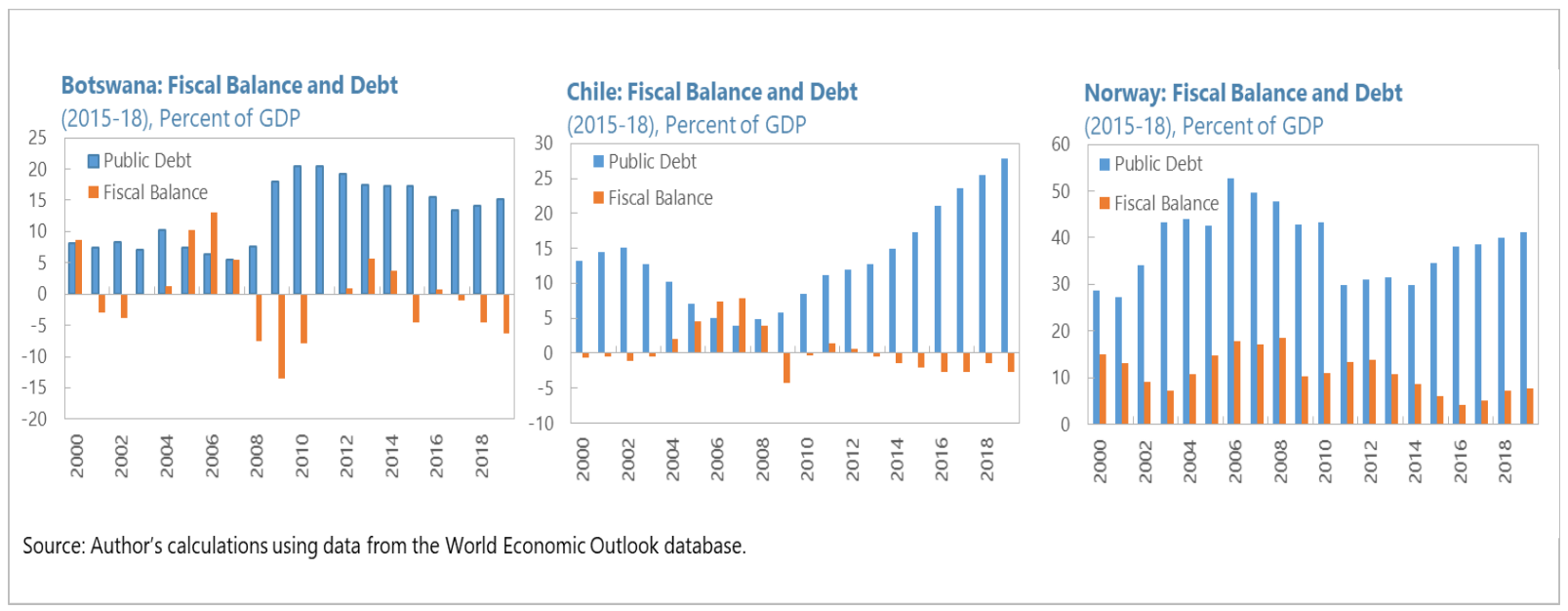


Botswana's fiscal framework includes an institutionalized ceiling rule on public debt that is achieved with two fiscal targets: a balanced budget fiscal rule and a spending rule (Lledó et al., 2017). The debt limit rule was introduced by the Stock, Bonds, and Treasury Bills Act of 2005. It caps both total domestic debt and total foreign debt at 20 percent of GDP. The spending rule was introduced in 2006 as a limit of 40 percent of GDP on government spending. By 2018, the spending rule had been breached only once, during the 2008 global financial crisis; and public debt had remained below 15 percent of GDP.

Although Norway's ceiling on the non-oil structural deficit in principle allows for some flexibility, the rule has been implemented as a de facto commitment to a positive budget balance. In principle, Norway's fiscal framework allows for deviations from the fiscal rule, during both expansions and recessions. For instance, in the event of large changes influencing the structural non-oil deficit, it is expected that the pace of adjustment to petroleum revenue spending would be spread across several years, based on the projected future real returns on the fund (Official Norwegian Reports, 2015). An expert commission reporting on the application of the fiscal rule is required to advise on how the fiscal rule should adapt to the exceptional circumstances (Government of Norway, 2020c). Yet, despite the fact that deviations from the fiscal rule would be tolerated if warranted by exceptional circumstances, Norway has consistently accumulated fiscal surpluses, including during the global financial crisis (Figure 6). This has helped keep the Norwegian public debt consistently below 25 percent of GDP, as of 2018.

Analysis of the financial position of Norway's public sector suggests that its stellar natural resource management framework and fiscal rule have put it into a strong position to face aging pressures, though some limited fiscal consolidation would eventually be needed. It has been estimated that although the public sector's assets exceeded liabilities by some 340 percent of GDP in 2018, the intertemporal net worth remained negative at about 240 percent of GDP when accounting for future liabilities related to old age pensions (Cabezon \& Henn, 2020). This is mainly because over the last 15 years, non-oil fiscal deficits have risen steadily from below 2 to above 7 per cent of non-oil GDP (Cabezon \& Henn, 2020). However, estimates suggest that complementing Norway's BIH framework with fiscal consolidation targeting a fiscal balance of 5 percent of non-oil GDP by the mid-2020s would make it possible to finance future pensions from the country's oil wealth (Cabezon \& Henn, 2020). One important takeaway from Norway's experience is that resource funds are the most effective at promoting fiscal sustainability when they are properly integrated with both the budget and the fiscal anchor, as was stressed by Poplawski-Ribeiro et al. (2012).

The Chilean fiscal rule experience has mainly had mixed success. Established in 2001, the Chilean fiscal rule requires a positive structural balance. The structural balance is defined as the central government balance evaluated at potential output and using the long-term copper price. The rule initially led to the accumulation of fiscal surpluses which helped contain the public debt to GDP ratio below 7 percent, prior to the onset of the global financial crisis. In fact, the Chile's net asset position strengthened from - 31/4 percent of GDP in 2000 to $19 \frac{1}{2}$ percent in 2008, 
against the background of increasing copper prices. Since then, public debt-to-GDP has increased relatively rapidly, reaching the level of 25 percent of GDP in 2018 . However, by all standards, Chile's debt level still remains relatively low for a middle-income country.

Chile's experience has proved that fiscal rules can become ineffective in difficult times if they are not sufficiently constraining. In practice, Chile's fiscal framework allows the government administrations to change the structural balance target as desired. In fact, the structural target has been modified multiple times, despite the requirement by the Fiscal Responsibility Act of 2006 that incoming governments should announce structural fiscal targets for the full length of their mandate within the first 90 days of their administration (Lledó et al., 2017). From 2001 to 2007 , the structural balance target was a surplus of 1 percent of GDP. In 2008 , the target was brought down to a surplus of 0.5 percent of GDP. In 2009, the target was changed to a zero structural balance, and a de facto escape clause was introduced to accommodate the countercyclical measures implemented in the context of the global financial crisis. In 2010, an adjustment path was specified to get the structural balance to converge to 1 percent of GDP by 2014. In 2015, the fiscal rule of a balanced structural budget was temporarily abandoned with the plan that it would be reinstated in 2018 after a gradual adjustment path of fiscal consolidation that would continue to support pro-growth expenditure in infrastructure and education.

One lesson from Chile's experience is that more predictability and a stronger anchor for fiscal policy, especially after deviations can enhance commitment to the fiscal rule. It is good practice to embed clear guidance on medium-term objectives for the structural balance and net assets in the fiscal rule itself. An explicit escape clause to allow discretionary policy in the event of large, clearly defined shocks usually helps enhance clarity while preserving flexibility.

\section{Natural resources, poverty, and inequality}

Most often, resource-rich countries have been unable to transfer an appropriate share of the resource dividend to those at the bottom of the market income distribution. In fact, many households in resource-rich countries still live below the $\$ 1.90$ dollar a day poverty line (Figure 8). The evidence also suggests that higher resource rents have generally not been associated with less market income inequality (Figure 7), except for a few countries in the Middle East and North Africa (MENA) region and the Central Asia region which have usually used government employment as a means of keeping people out of poverty (Adams and Page, 2003; IMF 2017). This indicates that resource-rich countries are generally not more successful than resource-poor countries at addressing inequality in opportunities. Equally surprisingly, the disposable income Gini in resource-rich countries has usually not been substantially lower than the market income Gini, suggesting that fiscal policy has not achieved much redistribution in these economies (Figure 7). 
Figure 7. Resource Rents and Inequality

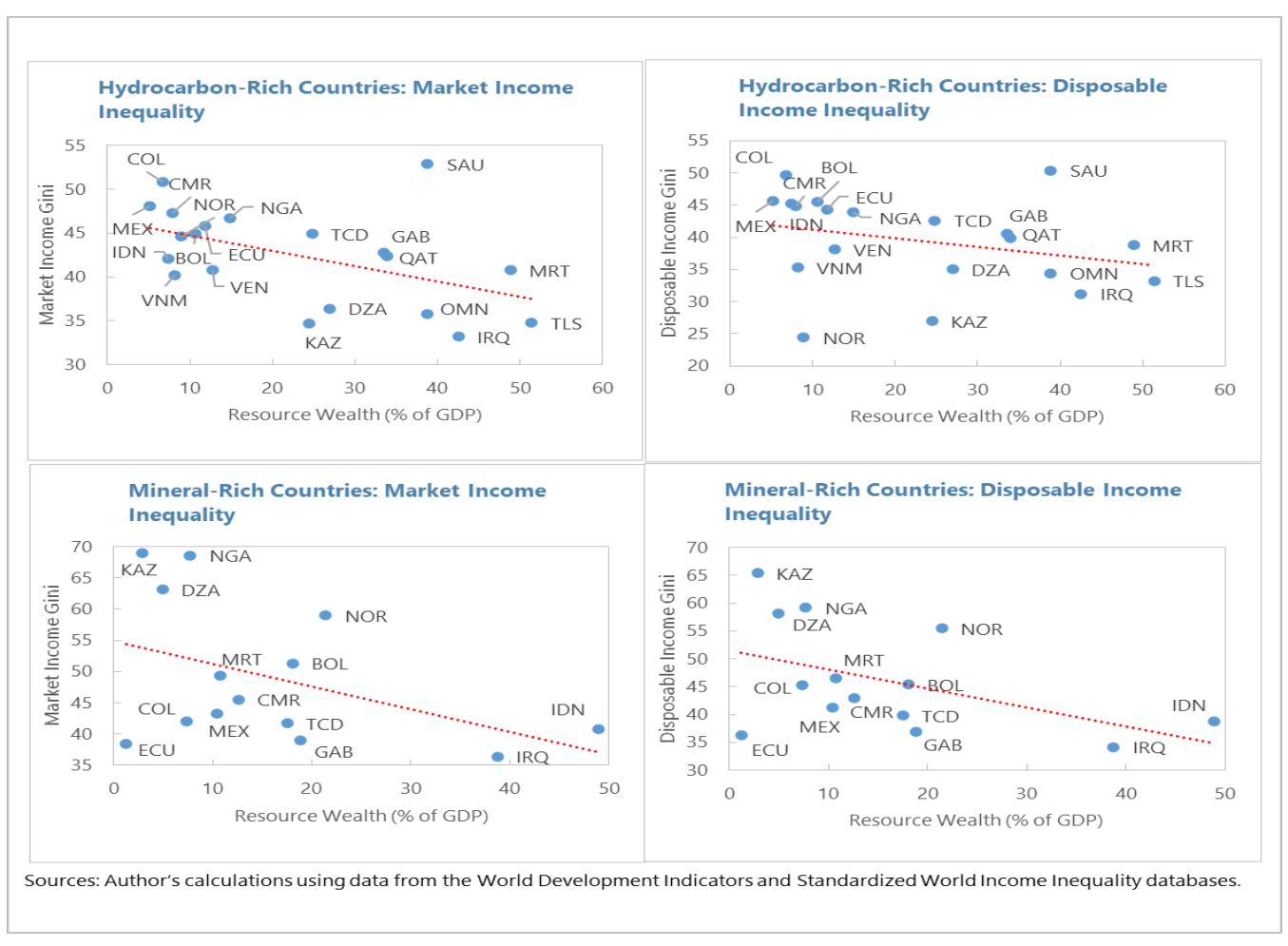

\section{Empirical studies suggest that resource wealth exacerbates rather than alleviates}

inequality. Eicher and Turnovsky (2003) documents a positive association, albeit weak, between the share of natural resource wealth in total wealth, and Gini market income inequality. Hartwell et al. (2019) finds evidence of a positive correlation between the lags of resource rents and market income inequality among countries with low levels of democracy, and a negative correlation among countries with relatively high levels of democracy. ${ }^{7}$ Lessmann and Steinkraus (2019) provides evidence of a strong and positive association between spatial inequality in the distribution of resource wealth and intergroup market income inequality. Economists have proposed different theories to explain this surprising and often unintuitive relationship between resource wealth and inequality.

The impact of resource abundance on education outcomes could be one fundamental reason why resource wealth does not seem to reduce inequality. To explain why market income inequality is higher in resource-rich Latin American countries compared to resource-poor East Asian countries, Leamer et al. (1999) proposes the explanation that natural-resourceintensive sectors absorb capital that might otherwise flow to manufacturing, hence delaying

\footnotetext{
${ }^{7}$ In the study of, democracy is measured by the democratic a ccountability score from the International Country Risk Guide (ICRG) da taset.
} 
industrialization by depressing workers' incentives to accumulate skills, and by the same token contributing to increasing in equality.

To explain the nexus between resource dependence, the level of democracy, and inequality, Hartwell et al. (2019) proposes that the influence of democracy operates through three distinct channels affecting equity. First, democracies allow a broader number of checks and balances, thus preventing the concentration of power over the control of resource rents into the hands of a few economic and political players. Second, because it allows citizens to sanction an unsatisfactory distribution of resource windfalls and indirectly decide over social spending programs, democracy may help spread the resource wealth more equitably than autocracy. Third, by enabling the diffusion of power and by encouraging social spending, democracy encourages citizens to maximize their own potential and invest to improve their human capital.

Bhattacharyya and Hodler (2014) proposes an alternative explanation linking resource abundance to a lack of will power to promote financial development. They argue that in countries with poor political institutions, easy access to resource rent makes incumbent governments unwilling to take on the challenge of improving contract enforcement. In the absence of strong contract enforcement, the private sector finds it difficult to obtain credit and undertake otherwise productive activities. Resource wealth therefore hinders financial development which is one channel through inequality could be reduced.

Resource-rich countries tend to have relatively lower spending in equity-promoting areas such as health and education. In fact, resource-rich developing countries invest markedly less in health and education (in terms of shares of GDP) than their resource-poor peers (Figure 8). Resource abundance has actually been shown to be negatively correlated with spending on education (Cockx, \& Francken, 2016) and spending on health (Cockx, \& Francken, 2014), including after controlling for GDP and other relevant factors. One possible explanation is that resource-rich countries tend to have opaque public finances and a lack of government accountability, both of which allow government officials to self-appropriate the economy's resources and conduct inefficient policies that serve their own interests. These government failures are not unique to resource-rich countries, but are exacerbated by the rent-seeking opportunities created by resource wealth. Thus, resource-rich societies need to build institutions capable of supporting human capital accumulation, which is fundamental for development and inclusive growth. 
Figure 8. Poverty and Spending in Health, Education in Resource-Rich Countries

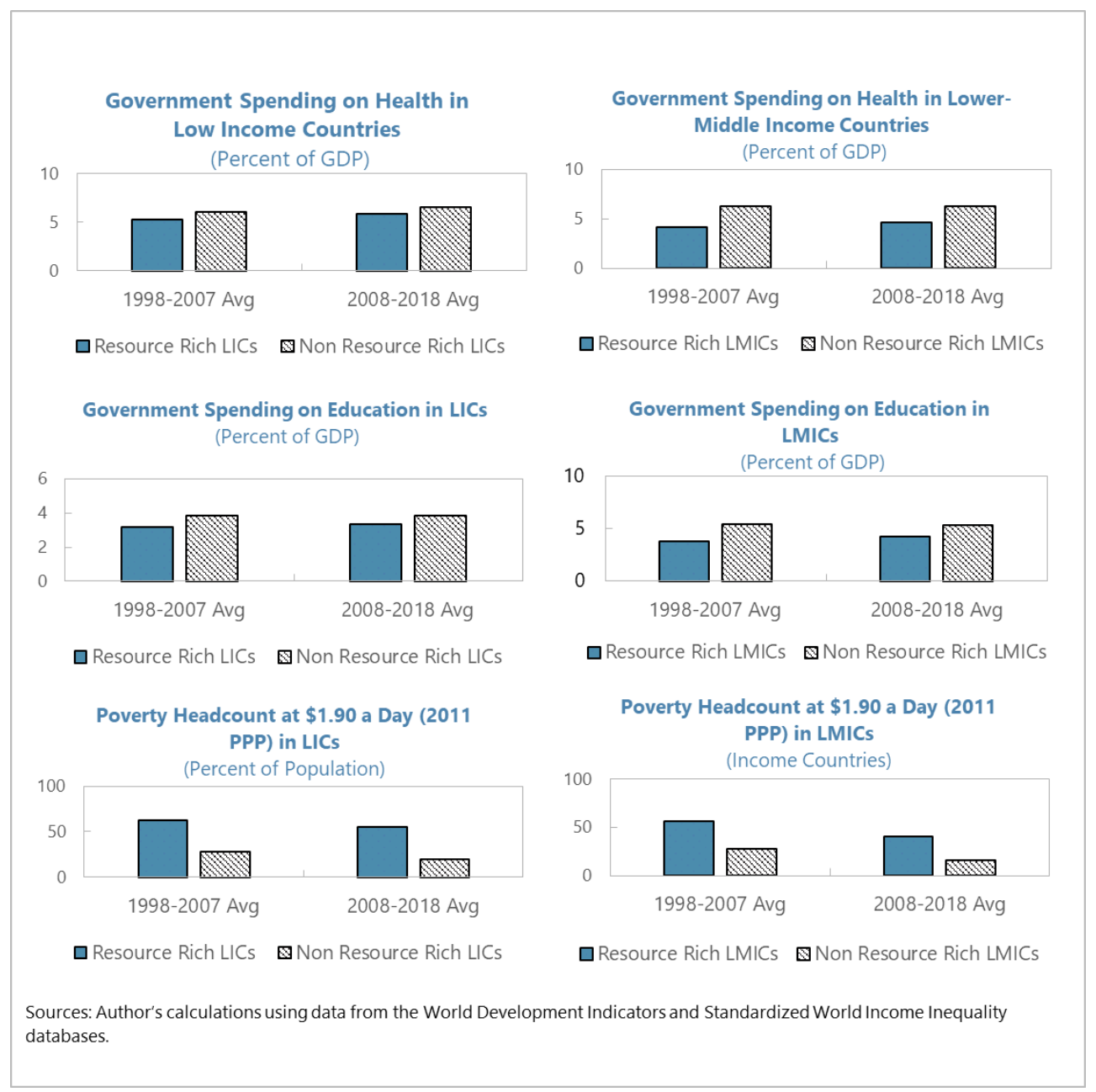

Tackling poverty and inequality requires investing earnestly in human capital, and creating budget space to assist the poor and vulnerable. This requires commitment to strong fiscal discipline to make sure that the funding base for education and health spending, but also social protection measures, is not eroded by commodity busts. It also requires a reprioritization of spending to focus on measures that effectively reach the poor. This could for instance involve abandoning costly fuel subsidies that primarily benefit the wealthy, and freeing up resources to invest more in health, education, unemployment insurance, school feeding programs, and cash transfers. The pioneering experience of Latin America with cash transfers that are conditioned on children's attendance to school or health clinic programs has shown that well designed cash transfers programs could be an effective approach to reducing inequality (Lustig et al., 2013).

\section{Structural policy: making the case for economic diversification}

Effective diversification policies can help countries sustain high long-term growth and escape the trap of resource dependence. The experiences of Malaysia and Chile present two tales of economic diversification that other resource-rich countries could learn from. 


\section{A. The experience of Malaysia with economic diversification}

Early on, Malaysia shifted away from its import substitution strategy. In the early 1960s, Malaysia' s trade policy focused on an import substitution strategy (Lim, 1987). Malaysia's exports at the time relied heavily on tin and rubber production which was declining. This prompted the government to promote the development of new exports markets, but also to pursue vertical policies toward higher-value-added activities related to natural resource industries, including to support the export of oil refinery by the state company after oil was discovered in the $1970 \mathrm{~s}$. In fact, in the 1970s, Malaysia was one of the earliest oil exporters to scale down its import substitution strategy to rely more on an export promotion policy (Cherif and Hasanov, 2015).

One key feature of Malaysia's diversification program was the strong involvement of the government which fiercely promoted Malaysian exports. To diversify Malaysia's export base, the government rallied the efforts of the private sector, initially focusing on promoting the development of the palm oil industry (agricultural diversification), but later supplementing this with industrialization policies focused on export promotion. Agricultural diversification policies in Malaysia consisted in providing cash, tax incentives, and direct government support to promote the cultivation, processing, and exports of palm oil and palm oil products. Industrialization policies mainly focused on an export-oriented development strategy centered around free-trade zones, and were accompanied with trade liberalization and the promotion of human capital accumulation through support for education and skills development (Friska, 2013).

These strategies initially produced spectacular results. Manufacturing exports rose from about 6 percent of total exports in the early 1970 s to more than 70 percent in the early 2000 s. Following the creation of the Multimedia Super Corridor (MSC) in 1996 to promote tax incentives favoring the IT sector, the share of the IT industry rose to more than 70 percent of manufacturing exports by the early 2000s (Friska, 2013). However, since then, the process of structural transformation has stalled, indicating the need for a new strategy to reach higher value-added markets.

One reason which may explain why Malaysia's progress has stalled is the lack of innovation and technology diffusion. In Malaysia, the process of industrialization has been mainly carried out by multinationals not keen on transferring technology to local firms, unlike in South Korea and Taiwan Province of China where innovation has been mainly carried out by local firms (Cherif and Hasanov, 2015). As a result, growth in total factor productivity in Malaysia has lagged behind that of these two Asian Tigers, making it difficult for Malaysia to continue its process of structural transformation by further moving up the value-added ladder. The Malaysian experience hence suggests that a government-led diversification program can effectively promote new export markets early on, but would require research and development, along with technology diffusion to take the country to the technological frontier. The examples of "spin off" firms in Taiwan Province of China and "chaebols" in South Korea illustrate how close collaboration and long-term relationships with international firms can nurture innovation by local firms. 
The approach of the government of Taiwan Province of China to technology diffusion has been summarized in two pillars (Cherif and Hasanov, 2015): (1) an active participation of public and quasi-public research institutes which would spin off firms introducing new technologies; and (2) massive public investment in training engineers abroad to support the formation of a "technical community" with valuable technical experience and informal connections with the Silicon Valley. As explained in Cherif and Hasanov (2015), The Industrial Technology Research Institute (ITRI) was created in 1973 to negotiate licenses or technologysharing agreements with US electronics firms. Typically, ITRI's staff would be sent for training in the production facilities of US partners and upon their returns, would set up an experimental production unit within ITRI's facilities. Once this stage was passed, the team of engineers and technicians involved in the new technology would then form a "spin-off" firm with about 40-50 percent of the initial capital coming from the government. When the government of Taiwan Province of China ended its spin-off program in the mid-1990s, the leading firms in the electronics sector were already investing heavily in $R \& D$ and were using the best technologies available (Cherif and Hasanov, 2015).

South Korea led an export-driven and very ambitious strategy to promote technology diffusion. The strategy mainly consisted of providing pecuniary incentives for South Korean firms to create global brands (chaebols) with strong footholds in several industries. These industrial conglomerates were encouraged to export immediately, and this, according to Cherif and Hasanov (2015) would be precisely the reason why the automaking industry expanded more rapidly in South Korean than it did in Malaysia, despite facing initially similar challenges in terms of technology acquisition and skills adequacy. Chaebols would receive loans with low and often negative real interest rates that were often made conditional on explicit and quantified exports targets (Cherif and Hasanov (2015)). Stiff international competition therefore forced the chaebols to operate at the technological frontier very early on. Knowledge spillovers across the different industries in which the chaebols operated further supported overall productivity growth.

\section{B. The experience of Chile with economic diversification}

Economic diversification effectively took off in Chile in the 1980 s after trade liberalization reforms and successful efforts to bring technological innovation into strategic sectors. Starting in the mid-1970s, Chile pursued aggressive unilateral trade liberalization by slashing out imports tariffs and turning away from the import substitution strategy that had been in place since 1934 (Friska, 2013). This set the stage for an export-oriented growth strategy focused on creating new export markets by introducing and disseminating new technologies in selected sectors. Largescale technology diffusion was made possible by foreign direct investments, especially in the wine sector, but also by the work of Fundación Chile as a "do thank" in the fish and fruits sectors (World Bank, 2014). ${ }^{8}$ The Innovation for Competitiveness Fund (ICF) created in 2006 played a catalytic

\footnotetext{
${ }^{8}$ Fundación Chile is a venture capitalist created in 1976 as a nonprofit private public partnership between the Chilean government and the American conglomerate ITT (United Nations, 2006).
} 
role as well, by establishing a framework for the use of windfalls from copper exports to support different programs for science and research and development (R\&D). This helped finance and monitor high growth start-up firms, and led to significant investments in advanced skills, including scholarships to enroll Chileans into top global universities (OECD/WTO, 2019).

What made Fundación Chile successful as a vehicle for technology transfer was its role as a not-for-profit venture capitalist. Technology transfer in Chile usually worked as a two-stage process (Lebdioui, 2019). Initially, Fundación Chile would create firms to demonstrate the new technologies. Then, after the industry had become viable, these firms would be sold to the private sector. From the very beginning, Fundación Chile would share its knowledge with private entrepreneurs which in this way, could freely access innovative technologies. Overall, Fundación Chile created around 70 firms (Lebdioui, 2019).

In essence, Fundación Chile demonstrated viable business models through the companies it created. In the case of the salmon industry, the acquisition of the American company Domsea Farms and the creation of Salmones Antarctica by Fundación Chile in 1981 helped bring production levels from very low levels up to around 1,000 tonnes by 1988 when Salmones Antarctica was sold (Lebdioui, 2019). Most importantly, this helped demonstrate to the private sector that the large-scale farming, breeding and production of salmon in Chile was technically and commercially feasible (United Nations, 2006). By the early 2000s, annual salmon production had surpassed 500,000 tonnes and salmon had become Chile's second largest source of export revenues after copper (Lebdioui, 2019). Similarly, in the fruits industry, Berries la Union, a company created by Fundacion Chile in 1980, helped elaborate a profitable business model for the cultivation of berries in Chile by disseminating the technology of cold storage systems (Agosin et al., 2010).

Overall, Chile's diversification strategy has met with only partial success as merchandise exports remains essentially resource-based. In 1980, Chile's merchandise exports were poorly diversified: mining accounted for 64 percent of total merchandise exports; the agro-industry for 24 percent; and manufacturing for 9 percent. As of 2019, the overall picture shows only moderate improvements: the share of the agro-industry in Chile's total merchandise exports is relatively large at around 33 percent; but the share of the mining sector continues to be high at around 53 percent, while that of manufacturing continues to be low at around 13 percent. In comparison, in Malaysia, the export share of the agro-industry sector fell from 46 percent in 1980 to 11 percent in 2019, while that of the nonrenewable resource sector (essentially fuel and mining) fell from 35 percent in 1980 to 18 percent in 2019, contrasting sharply with an increase from 19 percent to 70 percent for the manufacturing sector. In Korea and Taiwan Province of China which are both resource-poor economies, the share of manufacturing products in total merchandise exports which was already very high in 1980 (at 89 percent for Korea and 88 percent for Taiwan Province of China) continues to be very high by all standards (at 87 percent for Korea and 91 percent for Taiwan Province of China, as of 2019). 
As a result of the focus on the agro-industrial sector, Chile's diversification strategy has led to slow total factor productivity growth. In fact, despite the multiple innovations introduced in the Chilean wine, fishing, fruits, and meat industries, total factor productivity growth has stagnated since the 1970s, with Chile lagging significantly behind the Asian Tigers, but also behind Malaysia (Cherif and Hasanov, 2015). Chile's slow productivity growth has been attributed in part to significant entry barriers and regulatory complexity (OECD, 2018) which prevent small and medium enterprises (SMEs) from innovating and competing in sectors in which the Chilean government is not leading with a top-down approach to innovation and growth. For instance, in 2018, only 2 percent of Chilean SMEs participated in international trade-(OECD, 2018). More so, the concentration of Chile's innovation efforts in the agro-industrial sector has not allowed to fully benefit from cross-sectoral knowledge spillovers catalyzed by exporting manufacturing firms ((Herzer et al., 2006) and (Wei \& Liu, 2006)). This could explain why productivity growth in Chile has been much lower than it has been in Malaysia, Korea, and Taiwan Province of China in which the manufacturing sector has grown more rapidly.

\section{Conflict and Fragility}

Conflict and fragility exacerbate the risk of misuse of resource wealth. Of the 36 countries identified as fragile in 2019 , half were resource-rich countries in the 2000 s, in the sense that they had an average ratio of natural resource rents-to-GDP that exceeded 10 percent. ${ }^{9}$ Of these 18 resource-rich fragile countries, only five were not low-income countries (Iraq, Libya, Myanmar, Papua New Guinea, and Timor-Leste). This tight nexus between resource wealth, economic development, and state fragility has been explained by a negative impact of natural resources on the institutional climate and the state capacity in fragile countries (Chami et al., 2020). The effect of natural resources on state capacity operates through two channels.

First, natural resource windfalls fuel military spending and conflict. The basic mechanism is that natural resource wealth not only heightens the stake for conflict in institutionally weak countries, but it also contributes to the opacity of budget processes, thereby allowing for the prioritization of military spending over human capital development needs. In fact, in fragile states, resource wealth tends to be associated with a higher ratio of military spending over GDP (Figure 9). Consistent with this fact, Deléchat et al. (2018) shows that a relatively high level of natural resource rents is associated with a relatively low probability that a fragile country would eventually

9 The list of fragile and conflict-affected situations (FCS) is released annually by the World Bank Group (WBG). Fra gile countries a re countries with high levels of institutional and social fra gility, identified based on CPIA scores, and countries affected by violent conflict, identified based on a threshold number of conflict-related deaths rela tive to the population.

https://www.worldbank.org/en/topic/fragilityconflictviolence/brief/harmonized-list-of-fragile-situations 
exit fragility by reaching a Country Policy and Institutional Assessment (CPIA) score above what could be considered a threshold for institutional resilience. ${ }^{10}$

Figure 9. Military Spending and Resource Wealth in Low-Income Countries

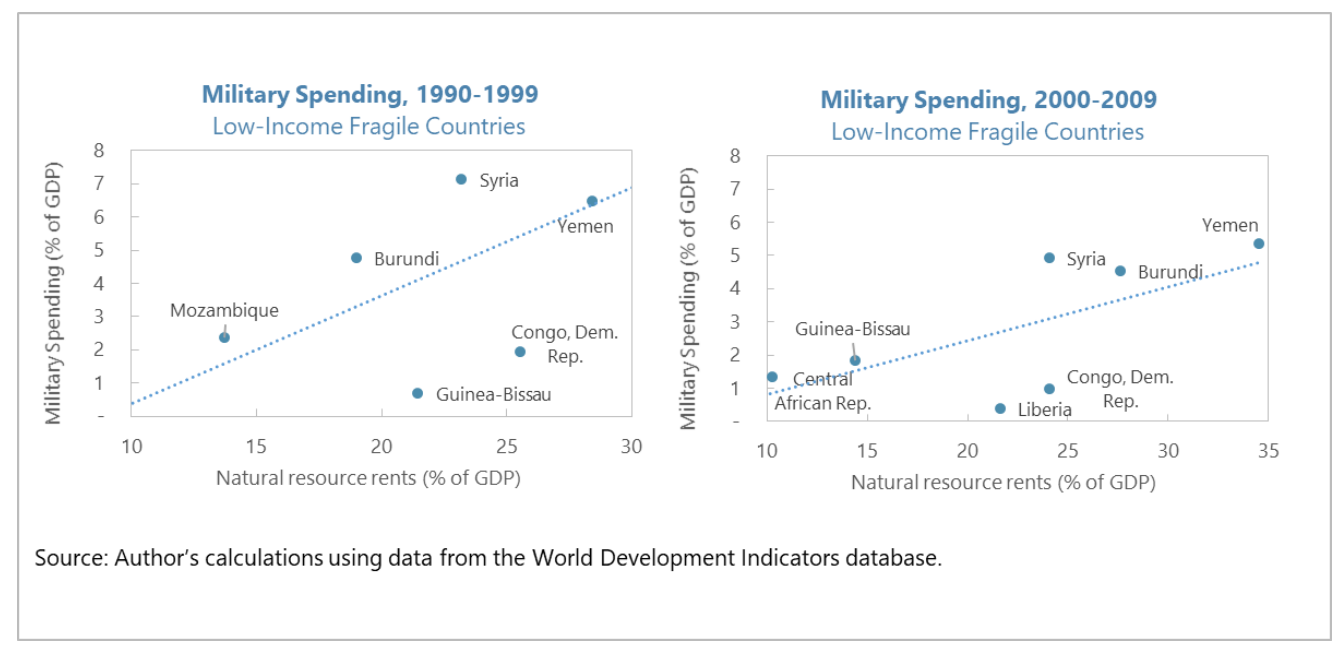

Second, dependence on natural resources weakens fiscal capacity in fragile countries. Natural resource wealth undermines efforts to collect non-resource revenues -particularly VAT, corporate and trade taxes - (Crivelli and Gupta, 2014). In doing so, natural resource wealth contributes to weakening fiscal capacity in fragile countries (Deléchat et al., 2018). Weak capacity in turn challenges the management of government revenues. This for instance creates hurdles for the completion of public infrastructure projects in the face of reversals in commodity booms, leading to additional inefficiencies. More generally, fragility makes a strong case for strengthening institutional capacity to promote sound fiscal policy and a conscious sharing of the resource wealth across generations.

History teaches us that improving governance and investing in human capital would be the way out of the vicious cycle of resource dependence and poverty. Of the 52 countries classified by the World Bank as low-income in 1995, only 28 had become middle-income countries by 2014 , while the 24 other countries had remained low-income countries, including among them 12 resource-rich countries of which 8 are currently classified as fragile-conflict states. (World Bank, 2018). The 24 countries that were unable to graduate to the status of middle-income countries also had the lowest rankings on most dimensions of institutions and governance quality as measured by the World Governance Indicators - voice and accountability, political stability and absence of violence, government effectiveness, regulatory quality, rule of law, and control of corruption(World Bank, 2018). Among the 28 countries that successfully made the transition to the middle-

\footnotetext{
${ }^{10}$ The CPIA - Country Policy and Institutional Assessment - rates countries against a set of 16 criteria grouped in four clusters: (a) economic management; (b) structural policies; (c) policies for social inclusion and equity; and (d) public sector management and institutions. https:/ida.worldbank.org/financing/resource-management/ida-resourceallocation-index
} 
income status, 15 countries considered resource-rich effectively invested in other forms of assets than natural capital. However, among these 15 countries, only those who invested significantly in human capital were able to cut their poverty rates by half.

\section{Strengthening governance in the management of resource wealth}

The positive role of good governance in the management of natural resource wealth cannot be overstated. Strong institutions are essential to establishing effectiveregulatory frameworks and promoting accountability and transparency which together condition a country's capacity to exit the vicious cycle of resource dependence and poverty discussed earlier. Steps usually taken by governments in resource-rich countries to promote accountability and transparency includejoining the Extractive Industries Transparency Initiative (EITI) and endorsing the Santiago Principles for the management of Sovereign Wealth Funds (SWFs).

\section{The Santiago Principles}

The Santiago Principles are a voluntary code of 24 guidelines for the management of SWFs. These guidelines were proposed in 2008 through a joint effort between the IMF and the International Working Group of SWFs. They are organized in three blocks aiming at three different objectives: (1) encouraging SWFs to publicly disclose their legal frameworks and policy purposes; (2) promoting a sound governance framework that clearly and effectively divides roles and responsibilities among a SWF's constituents; and (3) supporting appropriate investment and risk management frameworks for SWFs (Tapsoba, 2014). As of 2020,33 countries have signed to the Santiago Principles. ${ }^{11}$

\section{The Extractive Industries Transparency Initiative}

Established in 2003, the Extractive Industries Transparency Initiative (EITI) is a global standard to support transparency and accountability in the management of extractive resources in resource-rich countries. ${ }^{12}$ The EITI promotes transparency by publishing independent reports on resource revenues, and by requiring that governments engage with civil societies as a way of disseminating information on the revenues collected. EITI reports compare company information on payments from of oil, gas, and mining operations with government information on revenues from these sectors. Signatories countries lose credibility in the management of their natural resource wealth if they fail to produce information on resource revenues that can be reconciled with payments data from extractive industry (EI) companies. Adhering to the EITI

\footnotetext{
${ }^{11}$ These countries are: The United Arab Emirates, Rwanda, the United States, France, Mexico, Italy, China, Spain, Panama, Senegal, Angola, Australia, Singa pore, Na uru, Ireland, Morocco, Ka zakhstan, Ma laysia, Korea, Kuwait, Libya, Iran, New Zea land, Nigeria, State of Palestine, Qatar, Russia, Oman, Azerbaijan, Trinidad and Tobago, Botswana, Timor-Leste, and Turkey.

https://www.ifswf.org/our-members

${ }^{12}$ https://eiti.org/who-we-are
} 
therefore provides additional incentives for governments to truthfully report on the revenues collected. Ultimately, greater transparency on the amount of resource revenues collected by the government could lead to more inclusive spending policies as informed citizens make the government accountable for its poor choices. As of 2020, 53 countries are members of the EITI; three countries have lost their membership for failing to meet EITI standards (Equatorial Guinea, Gabon, and Yemen); and four have withdrawn from the EITI (Azerbaijan, the United States, Niger, and Solomon Islands). ${ }^{13}$

\section{Conclusions}

Many countries have an economic structure dominated by resource wealth that is expected to be exhausted within a generation. These countries urgently need to design policies, especially maintaining appropriate fiscal frameworks, to share the benefits of the resource wealth equitably and sustainably across generations, and to mitigate the adverse economic and fiscal impacts of resource revenue volatility.

Resource-rich countries must overcome the challenge of poor governance and actively seek to diversify their economies with policies conducive to a friendly business climate. Only by doing so would they be able to leverage their resource wealth to positively transform lives, one generation at the time. This is particularly true for hydrocarbon producers for whom the quest for the decarbonization of the global economy to mitigate climate risks poses the threat of an economic collapse. To produce long-lasting results, efforts to diversify must be accompanied with an effective competition policy and the removal of bottlenecks to innovation and technology diffusion.

Exiting the trap of resource abundance and poverty requires significant and efficient investment in human capital. History has taught us that resource-rich developing countries which dedicate significant effort in fostering human capital accumulation are generally able to sustain high growth, reduce poverty significantly, and escape the state of fragility. To underpin such efforts, strengthening state capacity and transparency with the establishment of pro-growth institutions is undeniably the right place to start.

13 https://eiti.org/other-countries 


\section{REFRENCES}

Acemoglu, D., Johnson, S., \& Robinson, J. A. (2002). An African success story: Botswana.

Adams Jr, R. H., \& Page, J. (2003). Poverty, inequality and growth in selected Middle East and North Africa countries, 1980-2000. World Development, 31(12), 2027-2048.

Agosin, M. R., Larraín, C., \& Grau, N. (2010). Industrial policy in Chile. IDB Working Paper Series No. IDB-WP-170

Auty, R., \& Warhurst, A. (1993). Sustainable development in mineral exporting economies. Resources Policy, 19(1), 14-29.

Auty, R.M. (1994). Industrial policy reform in six newly industrializing countries: the resource curse thesis. World Dev. 22 (1), 1165-1171.

Backer, L. C. (2009). "Sovereign Wealth Funds as Regulatory Chameleons: The Norwegian Sovereign Wealth Funds and Public Global Governance through Private Global Investment." Georgetown Journal of International Law, Vol. 40, pp. 101-217.

Bhattacharyya, S., \& Hodler, R. (2014). Do natural resource revenues hinder financial development? The role of political institutions. World Development, 57, 101-113.

Bjørnland, H. C., \& Thorsrud, L. A. (2016). Boom or gloom? Examining the Dutch disease in two-speed economies. The Economic Journal, 126(598), 2219-2256.

Bruno, M., \& Sachs, J. (1982). Energy and resource allocation: a dynamic model of the "Dutch Disease". The Review of Economic Studies, 49(5), 845-859.

Cabezon, E., \& Henn, C. (2020). Norway's public sector balance sheet. Applied Economics Letters, 27(11), 930-936.

Cashin, P., J. McDermott, and A. Scott (2002). "Booms and Slumpsin World Commodity Prices." Journal of Development Economics 69 (1): 277-96.

Chami, R., Montiel, P., Espinoza, R. (2020). Macroeconomic Policy in Fragile States.

Cherif, R., \& Hasanov, F. (2015). The leap of the tiger: How Malaysia can escape the middleincome trap (No. 15-131). International Monetary Fund.

Cherif, R., \& Hasanov, F. (2019). The return of the policy that shall not be named: Principles of industrial policy (No. 19-74). International Monetary Fund.

Cockx, L., \& Francken, N. (2014). Extending the concept of the resource curse: Natural resources and public spending on health. Ecological Economics, 108, 136-149.

Cockx, L., \& Francken, N. (2016). Natural resources: A curse on education spending? Energy Policy, 92, 394-408.

Collier, P., Hoeffler, A. (1998). On economic causes of civil war. Oxf. Econ. Pap. 56, 563-595.

Collier, P. (2014). Savings from natural resource revenues in developing countries: Principles and policy rules. Revue d'economie du developpement, 22(HS01), 185-216. 
Corden, W. M., \& Neary, J. P. (1982). Booming sector and de-industrialisation in a small open economy. The economic journal, 92(368), 825-848.

Crivelli, Ernesto, and Sanjeev Gupta (2014). "Resource Blessing, Revenue Curse? Domestic

Deléchat, Corinne, Ejona Fuli, Dafina Mulaj, Gustavo Ramirez, and Rui Xu. "Exiting from Fragility in Sub-Saharan Africa (2018). "The Role of Fiscal Policies and Fiscal Institutions." South African Journal of Economics 86, no. 3 271-307.

Dungey, M., Fry-McKibbin, R., \& Linehan, V. (2014). Chinese resource demand and the natural resource supplier. Applied Economics, 46(2), 167-178.

Eicher, T. S., \& Turnovsky, S. J. (2003). Inequality and growth: theory and policy implications (Vol. 1). Mit Press.

Foster, V., Butterfield, W., \& Chen, C. (2009). Building bridges: China's growing role as infrastructure financier for Africa. The World Bank.

Frankel, J. A. (2003a). Experience of and lessons from exchange rate regime in emerging economies (No. w10032). National Bureau of Economic Research.

Frankel, J. A. (2010). The natural resource curse: a survey (No. w15836). National Bureau of Economic Research.

Friska P (2013). "Sustaining growth and enhancing economic diversification in Botswana": Staff Report on Common Policies for Member Countries, IMF Country Report SM/13/246 (Washington: International Monetary Fund).

Fum, R. M., \& Hodler, R. (2010). Natural resources and income inequality: The role of ethnic divisions. Economics Letters, 107(3), 360-363.

Gelb, A. H. (1988). Oil windfalls: Blessing or curse?. Oxford university press.

Goderis, B., \& Malone, S. W. (2011). Natural resource booms and inequality: theory and evidence. Scandinavian Journal of Economics, 113(2), 388-417.

Government of Norway (2015). Background: Norway's fiscal framework. Retrieved from https://www.regjeringen.no/en/whatsnew/Ministries/fin/press-releases/2015/expertcommission-reports-on-the-application-of-the-fiscal-rule/background-norways-fiscalframework/id2423652/

Government of Norway(2020a). “About the Fund”. Retrieved from https://www.nbim.no/en/thefund/about-the-fund/ on November 25, 2020.

Government of Norway (2020b). "Investment Mandate Global Pension Fund Global". Retrieved from https://www.nbim.no/en/organisation/governance-model/executive-boarddocuments/investment-mandate---government-pension-fund-global/ on November 25, 2020

Government of Norway (2020b). "Expert Commission reports on the application of the fiscal rule”. Retrieved from https:/www.regjeringen.no/en/aktuelt/expert-commission-reports-onthe-application-of-the-fiscal-rule/id2423498/ on April 24, 2020.

C)International Monetary Fund. Not for Redistribution 
Gylfason, T., 2001. Natural resources, education and economic development. Eur. Econ. Rev. 45, $847-859$

Hartwell, C. A., Horvath, R., Horvathova, E., \& Popova, O. (2019). Democratic Institutions, Natural Resources, and Income Inequality. Comparative Economic Studies, 61(4), 53 1-550.

Herzer, D., NOWAK-LEHMANN D, F., \& Siliverstovs, B. (2006). Export-led growth in Chile: Assessing the role of export composition in productivity growth. The Developing Economies, 44(3), 306-328.

Hillbom, E., \& Bolt, J. (2015). Changing income inequality and structural transformation: The case of Botswana 1921-2010 (No. 2015/028). WIDER Working Paper.

Humphreys, M., Sachs, J. D., Stiglitz, J. E., Soros, G., \& Humphreys, M. (2007). Escaping the resource curse. Columbia University Press.

Hutchison, M. M. (1994). Manufacturing sector resiliency to energy booms: empirical evidence from Norway, the Netherlands, and the United Kingdom. Oxford Economic Papers, 311-329.

Leamer, E. E., Maul, H., Rodriguez, S., \& Schott, P. K. (1999). Does natural resource abundance increase Latin American income inequality?. Journal of development Economics, 59(1), 342 .

Lim, C. P. (1987). Changes in the Malaysian Economy and Trade Trends and Prospects. In Trade and Structural Change in Pacific Asia (pp. 435-466). University of Chicago Press.

Iizuka, M. and J.P. Zanlungo (2016) 'Environmental Collapse and Institutional Restructuring: The Sanitary Crisis in the Chilean Salmon Industry', in A. Hosono, M. Iizuka and J. Katz (eds) Chile's Salmon Industry: Policy Challenges in Managing Public Goods, pp. 109-38. Tokyo: JICA Research Institute.

Iimi, A. (2007). Escaping from the Resource Curse: Evidence from Botswana and the Rest of the World. IMF Staff Papers, 54(4), 663-699.

International Monetary Fund (2008). "Norway's Oil Fund Shows the Way for Wealth Funds. IMF Survey. Retrieved at https://www.imf.org/en/News/Articles/2015/09/28/04/53/sopol070908a.

International Monetary Fund (2011). "Fiscal Policy and Employment in Advanced and Emerging Economies".

International Monetary Fund (2012). Macroeconomic Policy Frameworks for Resource-Rich Developing Countries", Background Paper 1.

International Monetary Fund, (2014) Article IV Consultation-Staff Report; Press Release; And Statement by the Executive Director for Chile.

International Monetary Fund (2015). The commodities roller coaster. A fiscal framework for uncertain times. Fiscal Monitor, chapter 1, October 2015.

International Monetary Fund (2017). "Public wage bills in the Middle East and Central Asia". Fiscal Affairs Departmental Paper Series. 
International Monetary Fund (2019). How to Mitigate Climate Change. Fiscal Monitor, chapter 1, October 2019.

Ismail, K. (2010). The Structural Manifestation of the 'Dutch Disease': The Case of Oil Exporting Countries. IMF Working papers, 1-36.

James, A. (2015). The resource curse: A statistical mirage?. Journal of Development Economics, 114, 55-63.

James, A., \& Aadland, D. (2011). The curse of natural resources: An empirical investigation of US counties. Resource and Energy Economics, 33(2), 440-453.

Keiko Takahashi, 2010, "Managing windfall revenues from LNG Projecys in Papua New Guinea”, Papua New Guinea: Staff Report on Common Policies for Member Countries, IMF Country Report No. 10/163. Selected Issues Paper (Washington: International Monetary Fund).

Kim, I., Baqir, R., Vardy, F., \& Ogata, K. (2005). Democratic Republic of Timor Leste: Selected Issues and Statistical Appendix. International Monetary Fund Country Report, (03/228).

Kim, Seong Sook (2014). Providing Adequate Old-Age Pensions in the Republic of Kore, in Benedict.

Lama, R., \& Medina, J. P. (2012). Is exchange rate stabilization an appropriate cure for the Dutch disease. International Journal of Central Banking, 8(1), 5-46.

Lashitew, A. A., Ross, M. L., \& Werker, E. (2020). What Drives Successful Economic Diversification in Resource-Rich Countries?. The World Bank Research Observer.

Lebdioui, A. (2019). Chile's export diversification since 1960: A free market miracle or mirage?. Development and Change, 50(6), 1624-1663.

Lessmann, C., \& Steinkraus, A. (2019). The geography of natural resources, ethnic inequality and civil conflicts. European Journal of Political Economy, 59, 33-51.

Lledó, V., Yoon, S., Fang, X., Mbaye, S., \& Kim, Y.(2017). Fiscal rules at a glance. International Monetary Fund, 2-77.

Lustig et al. (2013). "The Impact of Taxes and Social Spending on Inequality and Poverty in Argentina, Bolivia, Brazil, Mexico, Peru and Uruguay: An Overview”, CEQ Working Paper No. 13, August.

Martin E., \& Perinet M. (2017). "Implementing the new CEMAC regional convergence framework", Staff Report on Common Policies for Member Countries, IMF Country Report 17/393 (Washington: International Monetary Fund).

Matsuyama, K. (1992). Agricultural productivity, comparative advantage, and economic growth. J. Econ. Theory 58, 317-334.

Nakatani, R. (2018). Adjustment to negative price shocks by a commodity exporting economy: Does exchange rate flexibility resolve a balance of payments crisis?. Journal of Asian Economics, 57, 13-35.

(CInternational Monetary Fund. Not for Redistribution 
OECD/UN. (2018). Production Transformation Policy Review of Chile: Reaping the Benefits of New Frontiers.

OECD (2018). OECD Economic Surveys: Chile 2018, OECD Publishing Paris, https://doi.org/10.1787/eco_surveys-chl-2018-en.

OECD/WTO (2019), Aid for Trade at a Glance 2019: Economic Diversification and Empowerment, OECD Publishing, Paris, https://doi.org/10.1787/18ea27d8-en.

Official Norwegian Reports NOU 2015: 9, Chapter 1, The Application of the Fiscal Rule: The assessments and main conclusions of the Commission (2015), 10.

Papyrakis, E., Gerlagh, R (2007). Resource abundance and economic growth in the U.S. Eur. Econ. Rev. 51 (4), 1011-1039.

Poplawski-Ribeiro, M., Villafuerte, M. M., Baunsgaard, M. T., \& Richmond, C. J. (2012). Fiscal frameworks for resource rich developing countries. Staff Discussion Note. International Monetary Fund.

Revenue Effort in Resource-Rich Countries," European Journal of Political Economy, Vol.35, pp.88-101.

Sachs, J.D., Warner, A.M. (1995). Natural Resource Abundance and Economic Growth. National Bureau of Economic Research (Working Paper No. 5398, December).

Sachs, J.D., Warner, A.M. (1999). The big push, natural resource booms and growth. J. Dev. Econ. 59, 43-76

Sánchez, M. T. D. (2011). Strengthening Chile's rule-based fiscal framework (No. 11-17). International Monetary Fund.

Sao Tome and Principe 2004). “Oil Revenue Management Law, Law 8/2004," São Tomé, December. Available on the Web at: http://www.anp-stp.gov.st.

Satter, A., \& Iqbal, G. M. (2015). Reservoir Engineering: The fundamentals, simulation, and management of conventional and unconventional recoveries. Gulf Professional Publishing.

Segura, A. (2006). Management of oil wealth under the permanent income hypothesis: the case of São Tomé and Príncipe (No. 6-183). International Monetary Fund.

Tapsoba, S. A.-J. (2014). "Designing a fiscal framework for Algeria” Algeria: Staff Report on Common Policies for Member Countries, IMF Country Report 14/34 (Washington: International Monetary Fund).

Torvik, Ragnar (2002). Natural resources, rent seeking and welfare. J. Dev. Econ. 67, 455-470.

United Nations (2006). A Case Study of the Salmon Industry in Chile. In Conference of Trade and Development. Transfer of Technology for Successful Integration into the Global Economy.

Van der Ploeg, F. (2010). Aggressive oil extraction and precautionary saving: Coping with volatility. Journal of Public Economics, 94(5-6), 421-433. 
von Haldenwang, C., \& Ivanyna, M. (2018). Does the political resource curse affect public finance? The vulnerability of tax revenue in resource-dependent countries. Journal of International Development, 30(2), 323-344.

Veisi, M. (2017). Essays on the links between natural resources, corruption, taxation and economic growth. The University of Manchester (United Kingdom).

Wei, Y., \& Liu, X. (2006). Productivity spillovers from R\&D, exports and FDI in China's manufacturing sector. Journal of international business studies, 37(4), 544-557.

Wills, S., \& van der Ploeg, R. (2014). Why do so many oil exporters peg their currency? Foreign reserves as a de-facto sovereign wealth fund. IMF New Perspectives.

Jarvis, M., Lange, G. M., Hamilton, K., Desai, D., Fraumeni, B., Edens, B., ... \& Ruta, G. (2011). The changing wealth of nations: measuring sustainable development in the new millennium.

World Bank. (2014). Fundacion Chile Incubator: Chile Case Study. Washington, DC. (C) World Bank.https://openknowledge.worldbank.org/handle/10986/20109License:CC BY 3.0 IGO."

World Bank (2011). The changing wealth of nations: measuring sustainable development in the new millennium.

World Bank (2018). The changing wealth of nations: building a sustainable future. 